\title{
Geochemical and Lu-Hf Isotope Systematic of Detrital Zircons from the Ordovician Sandstones of the Sol-Iletsk Arch (Russia, Northern Caspian, Borehole Ordovician-2)
}

\author{
Kuznetsov NB ${ }^{1,2,3,4 *}$, Belousova EA ${ }^{4}$, Romanyuk TV ${ }^{2,3,4}$ \\ ${ }^{1}$ Geological Institute, Russian Academy of Sciences, Russia \\ ${ }^{2}$ Schmidt Institute of Physics of the Earth, Russian Academy of Science, Russia \\ ${ }^{3}$ Gubkin Russian State University of Oil and Gas, National Research University, Russia \\ ${ }^{4}$ Australian Research Council Centre of Excellence for Core to Crust Fluid Systems/GEMOC, Macquarie University, Australia \\ *Corresponding author: Kuznetsov NB, Geological Institute, Russian Academy of Sciences, Gubkin Russian State University of Oil and Gas, Russia
}

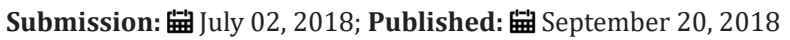

\begin{abstract}
The Sol-Iletsk arch is located at the south eastern edge of the East European platform (EEP), where EEP adjoins with the Southern Urals. The results of the integrated (U-Pb age, Lu-Hf isotopic system and trace-elements) study of detrital zircons (dZr) from the Ordovician sandstones (within Sol-Iletsk arch) reached by borehole Ordovician-2 are presented. The primary sources of Early Precambrian dZr were most likely the crystalline complexes of the Late Proterozoic Volgo-Sarmatian and Taratash orogens and Archean Volga-Uralia basement. However, for numerous dZr with ages younger 1.65Ga, it is not possible presently to unambiguously identify primary sources. Crystalline complexes with such ages are absolutely atypical for the south-eastern part of the EEP, but they occurred within parts EEP very remote from Sol-lletsk arch and beyond EEP.
\end{abstract}

Keywords: Detrital zircons; LA-ICP-MS; Ordovician; Sol-Iletsk arch; Northern Cis-Caspian

\section{Introduction}

The Ordovician is the time of maximal opening of the paleoceanic basins, the relicts of which are represented in the present-day structure of the Southern Urals [1-4]. It is assumed that the accumulations of Ordovician sequences of Sol-Iletsk arch were formed in grabens during the opening of the Paleo-Uralian ocean $[5,6]$. We have studied detrital zircons (dZr) of sandstones samples collected from borehole Ordovician-2 $\left(53^{\circ} 0^{\prime} 29.30^{\prime \prime} \mathrm{N}\right.$, $\left.56^{\circ} 56^{\prime} 36.40^{\prime \prime} \mathrm{E}\right)$. The sample K15-501 is taken from the core at a depth of $3439.7 \mathrm{~m}$ from a stack of sandstones lying at the base of the upper part of the Ordovician sequence. Sandstones are light, not layered poorly sorted medium-fine-grained differences with weakly incised fragments, mostly composed of quartz, less often quartzite, and single small scales of white mica. The main goal of the research is to test the ideas about the age and nature of the Ordovician deposits of the Sol-Iletsk arch, as well as to obtain information about the sources and feeding provinces.

\section{Geological Setting}

The Sol-Iletsk arch is located within the south-eastern part of the East European platform (EEP), where the Cis-Caspian depression junks the Pre-Uralian foredeep (Figure 1). Ordovician formations within this territory lie at considerable depths (2.5$3 \mathrm{~km}$ ) under Upper Devonian and younger sediments and have been reached by numerous boreholes. The Ordovician sequence has a three-member structure and a thickness of $>2000 \mathrm{~m}$. Its upper part is represented by mud-stones, siltstones and sandstones. The middle part is consisting of predominate sandstones (sometimes inter-bedded with siltstones and argillites) and the lower part is composed of quartzite sandstones [5-9]. Massive quartzite sandstones of the lower part lie at the base of the syn-rifted complex. The paleogeographic environment of the accumulation of Ordovician deposits is a shallow-marine zone of the terrigenous shelf with variable hydro-dynamics and a tendency to deepen eastward and south eastward (in modern coordinates) [1,10]. 


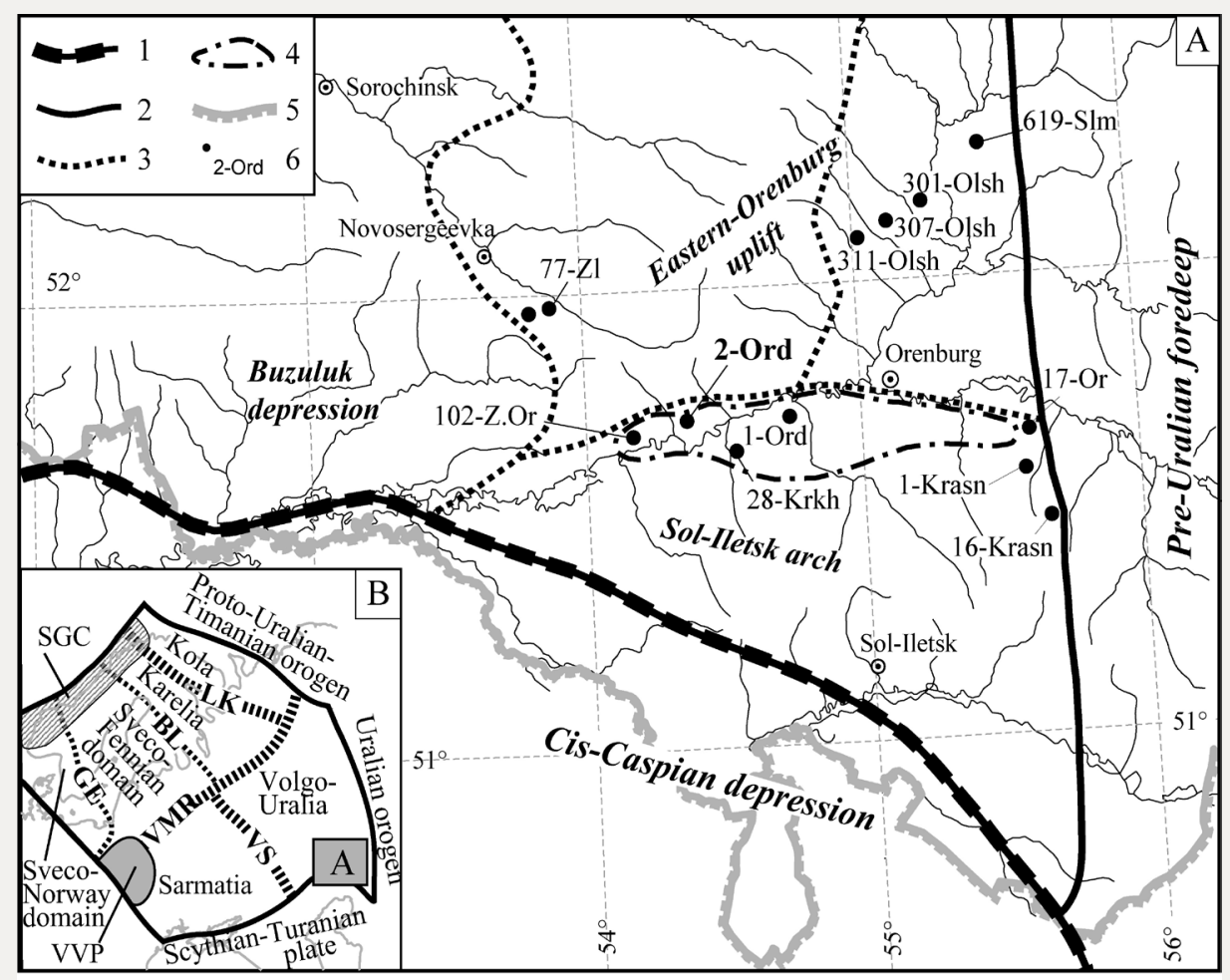

Figure 1: A. Tectonic scheme of the southeastern part of East European platform (EEP) and adjacent structures. 1-2- the boundaries of the EEP with the Cis-Caspian depression (1) and the Pre-Uralian foredeep (2); 3 - boundaries of tectonic units allocated within the southeastern part of the EEP; 4-contours of the Orenburg block; 5 - the state border of the Russian Federation and the Republic of Kazakhstan; 6-the position of boreholes and their abbreviations (1-Ord-Ordovician-1, 2-Ord-Ordovician-2, 17-Or-Orenburg-17, 102-Z.Or-Orenburg-102, 28-Krkh-Krasnokholmsk-28, 1-Krasn-Krasnoyarsk-1, 16-Krasn-Krasnoyarsk-16, 77-Z1-Zemlyansk-77, 301-Olsh-Olshansk-301, 307-Olsh-Olshansk-307, 311-Olsh-Olshansk-311, 619-Slm-Salmysh-619).

B. The segmentation of EEP basement. Dashed lines-orogens and sutures; the shaded area (SGC)-Scandinavian part of the Scandinavian-Greenland Caledonian orogens;

VS: Volgo Sarmatian; LK: Lapland Kola; VMR: Volyn Middle Russian; Sutures; BL: Botnia Ladoga; GE: Gothia Elv; VVP: Volyn Volcanic Province

\section{Methodology}

The technique consists of simultaneous study in situ and integrated analysis of the following three characteristics of individual zircon grains:

1. U-Pb-isotope system of zircon, which allows us to determine the age of generation of the zircon.

2. the contents of trace-elements (including rare-earth elements-REEs) in zircon, which makes it possible to predict a type of parental zircon rocks.

3. Lu-Hf-isotope system of zircon, which allows us to estimate $\varepsilon H f(t)$ and model age TDMC of parental zircon rocks.

Such an integrated approach makes it more reliably to identify the source rocks of $\mathrm{dZr}$ and to reconstruct the evolution of the feeding provinces than can be done based on $\mathrm{U}-\mathrm{Pb}$ ages of $\mathrm{dZr}$ only [11-16]. The study of dZr were carried out using the LA-ICPMS apparatus, a description of which, measurement technology, methodologies and constants used to process primary analytical data are given in $[17,18]$. At the first stage, the simultaneous measurement of the U-Th- $\mathrm{Pb}$ isotope system and trace-elements contents of dZr were executed, at the second stage, a separated study of Lu-Hf-isotope system of the selected dZr were executed.

\section{Analysis of the results of the $\mathrm{U} / \mathrm{Pb}$-isotope system of zir- cons study}

In existing technologies, the study of the $\mathrm{U} / \mathrm{Pb}$-isotope system of a zircon (or its part) makes it possible to evaluate its age simultaneously on two independent isotope systems, ${ }^{238} \mathrm{U}->{ }^{206} \mathrm{~Pb}$ and ${ }^{235} \mathrm{U}->{ }^{207} \mathrm{~Pb}$ (the radiogenic lead isotopes ${ }^{206} \mathrm{~Pb}$ and ${ }^{207} \mathrm{~Pb}$ are the final products of the radioactive decay of ${ }^{238} \mathrm{U}$ and ${ }^{235} \mathrm{U}$, respectively). Based on the measured ratios of ${ }^{206} \mathrm{~Pb} /{ }^{238} \mathrm{U}$ and ${ }^{207} \mathrm{~Pb} /{ }^{235} \mathrm{U}$, independent estimates of the age of zircon can be obtained. If these two ages are in good agreement (the concordant age of zircon), then this indicates that the $\mathrm{U} / \mathrm{Pb}$ isotope system of zircon is undisturbed and, on the diagram, $\ll^{206} \mathrm{~Pb} /{ }^{238} \mathrm{U}$ vs ${ }^{207} \mathrm{~Pb} /{ }^{235} \mathrm{U}$ » figurative points are located on a line called concordia.

If the age estimates are very different, then the points «move away» from this line, and the ages are classified as discordant. The results of each analysis are characterized by the discordance D, calculated by the formula:

$$
D=100 \% *\left[\text { age }\left({ }^{206} \mathrm{~Pb} /{ }^{238} \mathrm{U}\right) / \mathrm{age}\left({ }^{207} \mathrm{~Pb} /{ }^{206} \mathrm{~Pb}\right)-1\right]
$$

Ages with $10 \%>\mathrm{D}>-10 \%$ (i.e. $|\mathrm{D}|<10 \%$ ) are used to plot the histograms and probability density curves (PDC) of the ages $[19,20]$. The histograms and PDC are used for comparison with 
data characterizing the ages of crystalline complexes of potential erosion regions. For ancient zircons (age $>1 \mathrm{Ga}$ ), the used age is calculated based a ratio of ${ }^{206} \mathrm{~Pb} /{ }^{207} \mathrm{~Pb}$, for young zircons (age $<1 \mathrm{Ga}$ ) a ratio of ${ }^{206} \mathrm{~Pb} /{ }^{238} \mathrm{U}$. Ages with $|\mathrm{D}|>10 \%$ are used neither in statistical assessments, nor for the interpretation of the Lu-Hfisotopic system. However, they can be used to build discordias and other applications.

\section{Analysis of the trace-elements contents in zircons}

It has been reliably established that certain statistical trends and appreciable differences in the trace-elements contents are recorded for zircons from certain types of rocks [14,15,21-26]. Thus, in general, REE contents in zircons increase from the basic rocks (gabbroids and basaltoids), where the total content of REE are (5-10)x100ppm up to (1-2)x1000ppm, to felsic rocks (granitoids and their effusive analogs), where the total content of REE are (2-5) $\mathrm{x} 1000 \mathrm{ppm}$ and more, and in zircons from pegmatites can reach (1-3)x10000 of ppm (1-3\%). For such rocks as kimberlites, the typical total content of REE in zircons is usually less than 50ppm. In zircons from carbonatites and lamproites this parameter is large and can increase to $500 \mathrm{ppm}[14,15]$.

An important indicator is the Th/U ratio [26], which varies from 0.1 to 1 in most zircons. Low Th/U ratios are statistically considered to be characteristic of zircon crystals of metamorphic origin, unlike zircons of magmatic origin. However, there is still no consensus on the threshold $\mathrm{Th} / \mathrm{U}$ value: in different works, values Th/U from 0.5 to 0.1. Thus, value 0.5 in Kirkland et al [26], 0.2 in Hoskin \& Schaltegger [27], 0.1 in Teipel et al. [28]. High ratios of Th/ $\mathrm{U}>1.5$, together with other characteristics, are statistically inherent in zircons from mafic rocks $[25,29,30]$. It cannot be ignored that zircons with high $\mathrm{Th} / \mathrm{U}$ are sometimes formed in environments of high degrees of metamorphism [31].

Very low $\mathrm{U} / \mathrm{Yb}$ ratios are recorded for zircons from oceanic basalts NMORB $(\mathrm{U} / \mathrm{Yb}<0.1)$ [24]. Higher values $\mathrm{U} / \mathrm{Yb}$ are not unique and can be inherent in a wide range of rocks. However, in general, an increase in the ratio of $\mathrm{U} / \mathrm{Yb}$ and $\mathrm{Hf}$ content in zircons indicates the fractionation of their parent magmas and reflects the trends in their composition in the direction from the primitive towards the more enriched crust. The most statistically effective for the separation of zircons from oceanic basalts and zircons of continental genesis are the diagrams «U/Yb vs $\mathrm{Hf} »$ and «U/Yb vs Nb/Yb» [24]. Important information on zircons is carried by the REE spectra, which are represented in the form of values normalized to chondrite (we use the values for CI-chondrite by work Mc Donough and Sun 1995 in ppm: $\mathrm{La}=0.237 ; \mathrm{Ce}=0.613 ; \mathrm{Pr}=0.0928 ; \mathrm{Nd}=0.457 ; \mathrm{Sm}=0.148$; $\mathrm{Eu}=0.0563 ; \mathrm{Gd}=0.199 ; \mathrm{Tb}=0.0361 ; \mathrm{Dy}=0.246 ; \mathrm{Ho}=0.0546 ; \mathrm{Er}=0.16$; $\mathrm{Yb}=0.161$; $\mathrm{Lu}=0.0246$ ). A monotonic increase in the content of elements from light to heavy is typical for the normalized REE spectra of zircons, which is complicated by two anomalies: positive $\mathrm{Ce}$ and negative $\mathrm{Eu}$. The anomalies are characterized by values $\mathrm{Eu} /$ $\mathrm{Eu}^{*}$ and $\mathrm{Ce} / \mathrm{Ce}^{*}$ which are calculated by the ratio of the measured value of $\mathrm{Ce}$ or $\mathrm{Eu}$ in zircon, which is normalized to chondrite ( $\mathrm{CeCI}$ or $\mathrm{EuCI}$ ), to the predicted one as the geometric mean of the neighboring elements $\left(\mathrm{CeCI}^{*}=\sqrt{\mathrm{LaCIPrCI}}\right.$ or $\left.\mathrm{EuCI}^{*}=\sqrt{\mathrm{SmCIGdCI}}\right)$.
The REE spectra of zircons from granitoids are highly ordered for the heavy REEs: in the interval from Dy to Lu, the slope of the zircon spider-diagrams is rather stable. Its value is characterized by the $\mathrm{Yb} / \mathrm{Sm}$ (or $\mathrm{Lu} / \mathrm{Gd}$ ) ratio, and the contents of the heaviest REEs are $\mathrm{Yb}$ and $\mathrm{Lu}$ are used as a marks for classifications. Statistically, the zircon that crystallized in the igneous rock has a steeper slope for heavy REEs (larger $\mathrm{Yb} / \mathrm{Sm}$ values) than the crystal formed in rocks of high degrees of metamorphism [32].

Large statistics of the characteristics of zircon of igneous origin on trace-elements has already been collected, which makes it possible to predict with some high degree of probability certain specific types of its parent rocks. On this basis, the CART-algorithm developed a multi-step classification procedure in the form of a branching binary «tree» [15]. At each step at the branch point of the classification «tree», a value of a trace-element content obtained for a zircon is used to determine the further path along the «tree». Each final branch of the «tree» corresponds to a certain type of rocks (kimberlites, dolerites, nepheline syenites, etc.). Thus, based on the analysis of data on the content of trace-elements in zircon, the type of parental zircon rocks is statistically predicted.

The main purpose of using the CART-algorithm is the primary separation of zircons, the parent rocks for which there could be specific rare rock complexes, from zircons from granitoids and their effusive material analogues, which are the main sources of zircon. The latter, as a result of the classification, are subdivided according to the silicic acidity (i.e., by percentage of $\mathrm{SiO}_{2}$ in the rock) into three groups - rocks with reduced $\left(\mathrm{SiO}_{2}<65 \%\right)$, normal $\left(\mathrm{SiO}_{2}=65-75 \%\right)$ and increased $\left(\mathrm{SiO}_{2}>75 \%\right)$ silicic acidity. For the sake of brevity, these groups are called, respectively, «diorite», «granite» and «leucogranite» and corresponding zircons as «dioritic», «granitic», «leucogranitic».

Unlike zircons from «granites» or «diorites», which form large groups, are determined and interpreted statistically, the identification of zircons from specific rocks requires «manual» testing and debugging, primarily-checking the occurrence of measured trace-elements concentrations at boundary mark values or abnormal «sparks» for the concentrations of the elements that the CART-algorithm operates on.

\section{Analysis of the Lu-Hf-isotope system of zircons}

The main parameter characterizing the Lu-Hf isotope system of zircon is $\varepsilon_{\mathrm{Hf}}(\mathrm{t})$ (or $\varepsilon_{\mathrm{Hf}}$ to be shorter) which is the deviation of the measured ratio $\left({ }^{176} \mathrm{Hf} /{ }^{177} \mathrm{Hf}\right)_{\mathrm{Z}}$ in ten-thousandths to a similar ratio in chondrite (the bulk composition of the silicate Earth) at a given time. The positive values of $\varepsilon \mathrm{Hf}$ indicate the juvenile (mantle) origin of the magma of the parental zircon rocks, the negative values of $\varepsilon_{\mathrm{Hf}}<<0$ that magmatic isotope-mature material of the continental crust was involved [11,12,14,17].

To study the Lu-Hf-isotope zircon system, the contents of five isotopes ${ }^{176} \mathrm{Hf},{ }^{177} \mathrm{Hf},{ }^{176} \mathrm{Lu},{ }^{177} \mathrm{Lu}$ and ${ }^{176} \mathrm{Yb}$ were measured. The ${ }^{176} \mathrm{Yb}$ content is used for external measurement control [33]. Further, the calculation of $\varepsilon_{\mathrm{Hf}}(\mathrm{t})$ was carried out according to the formula: 
$\left.\varepsilon_{H f}(t)=\left\{\left[\left(1{ }^{176} H f f^{177} H f\right)_{Z}-\left({ }^{176} H f f^{177} H f\right)_{Z} \times\left(e^{\lambda t-1}\right)\right]\right]\left[\left({ }^{176} L u^{177} H f\right)_{C H}-\left(-176 L u^{\prime 177} H f\right)_{C H} \times\left(e^{x t-1}\right]-1\right]\right\} \times 10000$

where $\mathrm{t}$ is U-Pb-age of zircon, $\left({ }^{176} \mathrm{Hf} /{ }^{177} \mathrm{Hf}\right)_{Z}$ and $\left({ }^{176} \mathrm{Lu} /{ }^{177} \mathrm{Hf}\right)_{Z}$ are the measured values in zircon. The decay-constant $\lambda$ for ${ }^{176} \mathrm{Lu}$ was adopted as $\lambda^{176} \mathrm{Lu} 1.867 \times 10-11 \mathrm{yr}-1$ [34]. The current ratios in chondrite $\left({ }^{176} H f f^{177} H f\right)_{C H}=0.282785 \pm 0.000011$ and $\left({ }^{176} \mathrm{Lu}^{1{ }^{177}} \mathrm{Hf}\right)_{C H}$ $=0.0336 \pm 0.0001$ were taken from [35], in the depleted mantle $\left({ }^{176} \mathrm{Hf}^{\prime 177} \mathrm{Hf}\right)_{D M}=0.28325$ and $\left({ }^{176} \mathrm{Lu} /^{177} \mathrm{Hf}\right)_{D M}=0.0384$ from Griffin et al. [17].

For each grain of detrital zircon, based on its U-Pb age and the initial isotope ratios $\left({ }^{176} \mathrm{Hf} /{ }^{177} \mathrm{Hf}\right)_{\mathrm{Z}}$ initial, the model ages of the $\mathrm{T}_{\mathrm{DM}}$ mantle and the crustal substrate $\mathrm{T}_{\mathrm{DM}} \mathrm{C}$ (two-stage model) were estimated using the formulas:

$$
\begin{gathered}
T D M=1 / \lambda \times \ln \left\{1+\left[\left({ }^{176} H f^{177} H f\right)_{Z}-\left({ }^{176} H f /^{177} H f\right)_{D M}\right] /\left[\left({ }^{176} L u{ }^{177} H f\right)_{Z}-\left({ }^{176} L u /^{177} H f\right)_{D M}\right]\right\} \\
T_{D M}{ }^{C}=T_{D M}-\left[T_{D M}-t\right] \times\left[\left(F_{C}-F_{Z}\right) /\left(F_{C}-F_{D M}\right)\right]
\end{gathered}
$$

The parameter $\mathrm{F}$ for the average crust $(\mathrm{C})$, a studied zircon $(\mathrm{Z})$, and depleted mantle (DM) was calculated by the formula:

$$
F_{C, Z, D M}=\left\{\left[\left({ }^{176} L u / /^{177} H f\right)_{C, Z, D M}\right] /\left[\left({ }^{176} L u /{ }^{177} H f\right)_{C H}\right]-1\right\}
$$

The value of ${ }^{176} \mathrm{Lu} /{ }^{177} \mathrm{Hf}$ for the averaged crust was assumed to be $=0.015$, for more details, the rationale for the calculation scheme is set out in $[36,37]$. The $\mathrm{T}_{\mathrm{DM}} \mathrm{C}$ (the best accuracy of the estimates is not less $\sim 0.3 \mathrm{Ga}$ ) is an estimation of the minimum age of separation from the mantle of the crustal substrate of the parental rocks zircon. The integrated results of the dZr study are presented in the form of the diagram « $\varepsilon_{\mathrm{Hf}}(\mathrm{t})$ vs U-Pb-isotopic age of zircon» (hereinafter «Diagram $\varepsilon_{\mathrm{Hf}}$ "). The line CHUR characterizing the Chondritic Unfractionated Reservoir $\left(\varepsilon_{\mathrm{Hf}}(\mathrm{t})=0\right)$, the line of evolution of the depleted mantle (DM) and the reference lines of the evolution of the averaged continental crust (ages $0.5,1.0,1.5,2.0$, 2.5, 3.0, 3.5, and $4.0 \mathrm{Ga}$ ) also are shown on the «Diagram $\varepsilon \mathrm{Hf}$ ».

\section{Sampling processing, Description and analytical Re- sults}

The sample K15-501 was disintegrated manually in a cast-iron mortar. Crushed (up to $0.3 \mathrm{~mm}$ ) material is bruised in running tap water and after drying is separated in bromoform. Zircon grains contained in the concentrates of heavy $\left(>2.89 \mathrm{~g} / \mathrm{cm}^{3}\right)$ minerals been obtained by this way are characterized by a variety of color shades and sizes from the smallest fragments to $300 \mu \mathrm{m}$. About 500 randomly selected dZr were implanted in an epoxy disk and polished to half the "thickness" of the grains. Zircons were studied in cathode rays (Cathode Luminescence Image - CLI) and BackScattered Electrons (BSE). Selected zircons are mostly small, rarely $>100 \mu \mathrm{m}$. No crystallo-graphically perfect crystal with a clear CL-zoning was detected, which could be treated as primary magmatic grains of the first sedimentation cycle. All grains are well rounded, most up to round shape. Grains or parts of them are very different in CLI (from almost black to bright white) and are also variable in the internal structure.

There are grains or their fragments with a simple or complex oscillatory structure (magmatic origin), and almost monotonous
CLI (? Metamorphically altered grains or their fragments). Often grains consist of two (or more) different-sized parts, one of which is a fragment of a crystal with a good CL-zoning, and the other is a fragment of a crystal with virtually no CL-zoning. Almost all zircons contain inherited inclusions, metamict zones, and in some cases are broken by cracks. These are indications that zircons participated in magmatic/metamorphic processing [38]. In many zircons there are areas that can be treated as fragments of cores and rims. However, either small size of the areas or presence of disturbances did not allow placing two ablative craters with a diameter of $40 \mu \mathrm{m}$ in one grain in order to try to study in one zircon of cores and rims. Only a larger area was studied. For the 15 smallest grains, measurements were made with a crater size of $30 \mu \mathrm{m}$.

Measurements of the parameters of the U-Th- $\mathrm{Pb}$ isotope system in zircons were carrying out with Red-JG zircon standard for calibration, and Mud-Tank and 91500 as measured zircons for monitoring. During the measurements, the mean ages were Mud-Tank $=726 \pm 6 \mathrm{Ma} \quad(\mathrm{n}=10), 91500=1086 \pm 35 \mathrm{Ma} \quad(\mathrm{n}=12)$ and Red-GJ $=597 \pm 6 \mathrm{Ma}(\mathrm{n}=39) \mathrm{Ma}$, which agrees with the ages of these standards $[18,39]$. Measurement of the content of trace-elements in $\mathrm{dZr}$ was carried out for 22 elements, NIST standard was used for external control.

Measurements of the Lu-Hf-isotope system were monitoring by Mud-Tankand Temora II zircon standards. During the measurements, the average ratio of ${ }^{176} \mathrm{Hf} /{ }^{177} \mathrm{Hf}$ was $0.282565 \pm 0.000009(\mathrm{n}=12)$ for Mud-Tank and $0.282678 \pm 0.000012(n=6)$ for Temora II, which agrees with the values for these zircon standards [18,39]. A study of the U-Th-Pb isotope system of zircons was carried out for 120 grains (Figure 2). The first short information has been published in [40]. Correction for non-radiogenic lead was executed for 6 analyse (№ 4, 144, 188, 343, 345 and 450). The U-Pb values of ages characterized by large analytical error (№ 143 and 157) and/or high discordance $(|\mathrm{D}|>10 \%)$ were obtained for 31 analyzes. One grain (№ 33) has yielded a concordant but very ancient value of $4662 \pm 39 \mathrm{Ma}(\mathrm{D}=-0.41 \%)$. Such result requires a special additional study, so this analysis was also excluded from consideration. The remaining 87 dating were used to construct a histogram and a PDC (Figure 3). The minimum age is $561 \pm 4 \mathrm{Ma}$ (№ $32, \mathrm{D}=1.07 \%$ ), the maximum age is $3092 \pm 17 \mathrm{Ma}$ (№ $88, \mathrm{D}=2.17 \%$ ). The following peaks (supported by more than 3 values) are fixed on the PDC: 573 , 603, 685, 1263, 1584 and 2087Ma.

When studying the trace-elements content, the conditioning results were obtained for all grains (Figure 4-12). For grains № $112,118,130,145,201,250,267$ and 388, it was not determined -La content (the content is lower than the sensitivity of the instruments). Further, for calculation Ce anomalies, La content for these zircons was adopted $0.01 \mathrm{ppm}$. Grain № 52 has yielded very high P content (14325ppm), and № 2 and № 4 - elevated P content (10590 and 11063 ppm, respectively). For dZr, the size of which allowed a second crater of $40 \mu \mathrm{m}$ size and the U-Pb age estimates yielded acceptable concordance $(|\mathrm{D}|<10 \%)$, the Lu-Hf isotope zircon system was also studied. One of the grains (№ 88, 3092Ma) managed to "fit" two Hf craters: for these analyzes, close values of 
$\varepsilon_{\mathrm{Hf}}=5.94$ and 5.68 were obtained. The most $\mathrm{dZr}$ have yielded positive values of $\varepsilon_{\mathrm{Hf}}$ up to a maximum value of $\varepsilon_{\mathrm{Hf}}=11.7 \pm 0.8$. Several zircons with an age greater than 1.8Ga have yielded strongly negative

values of $\varepsilon_{\mathrm{Hf}}$ down to minimum value $-12.9 \pm 0.9$. Estimates of $\mathrm{T}_{\mathrm{DM}} \mathrm{C}$ are from 1.0 to $-3.7 \mathrm{Ga}$.

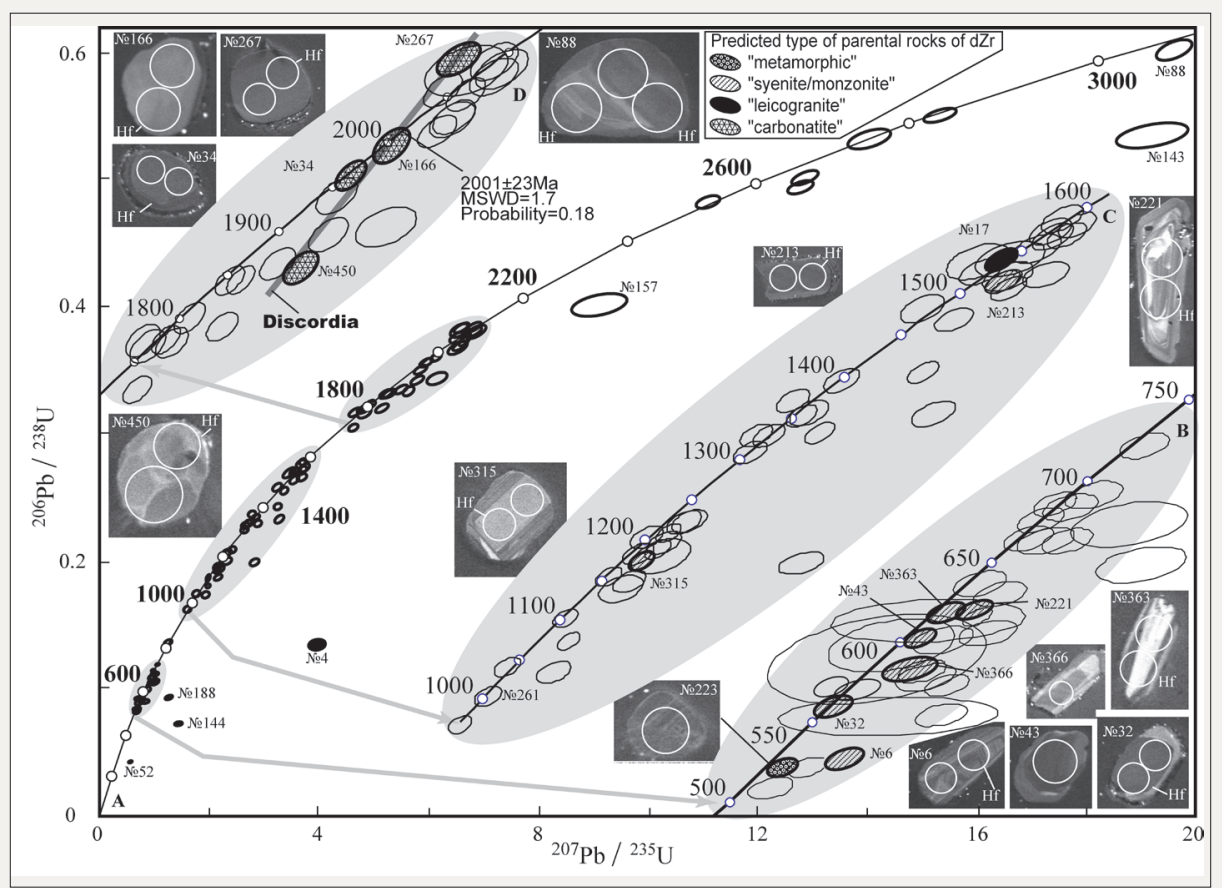

Figure 2: Results of U-Th- $\mathrm{Pb}$ isotope system study of $\mathrm{dZr}$ from sample K15-501. (A) Concordia and ellipses showing a 95\% confidence interval for all analyzes. Enlarged fragments of concordia at the grey background. Here and in the next Figs. CLimages of some grains are additionally shown, the diameter of the crater of laser ablation is 40 or $30 \mu \mathrm{m}$. The predicted type of parental rocks of $\mathrm{dZr}$ is estimated using the CART-algorithm by the content of trace-elements in $\mathrm{dZr}$. Zircons for which predicted type of parental rocks are "carbonatite", "syenite/monzonite" or "leucogranite", as well as a "metamorphic" (single zircon № 223) are shown by black filling or shading of ellipses.

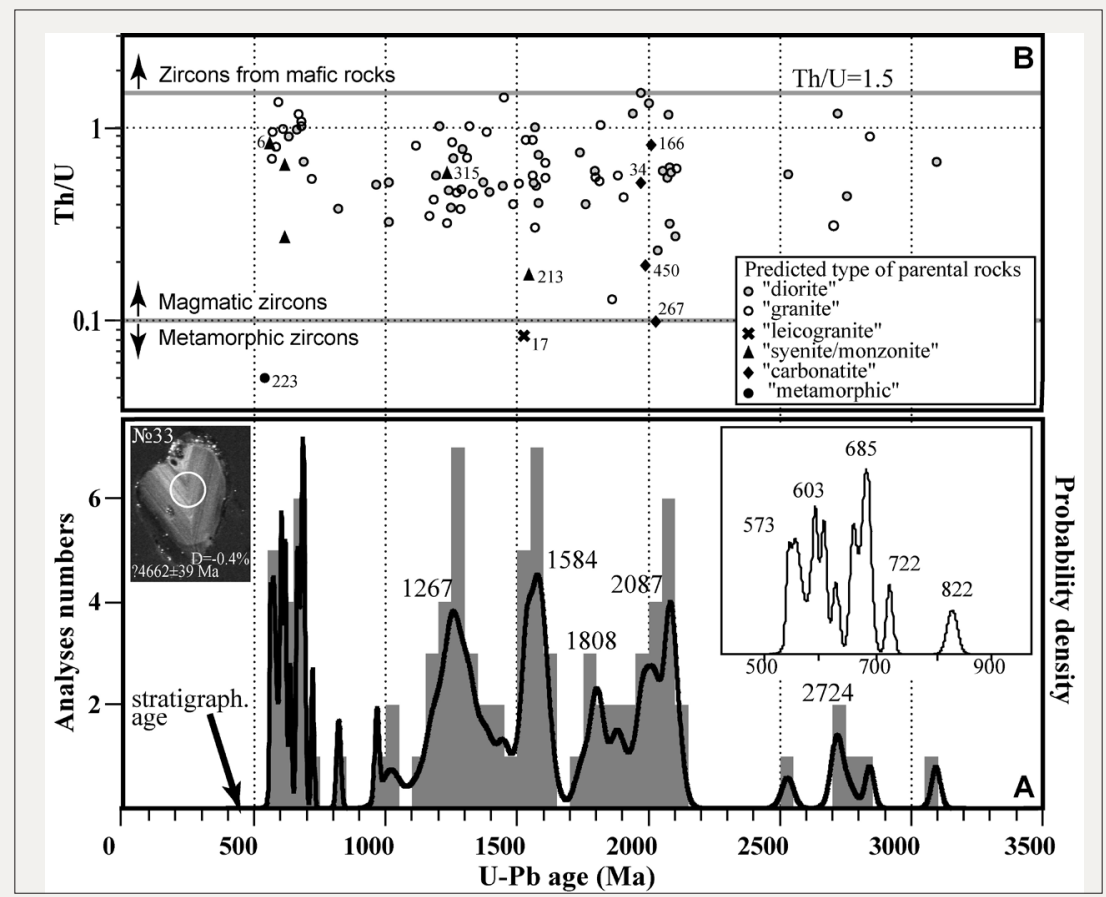

Figure 3: A. Histogram and PDC of U-Pb-isotopic ages ( $|\mathrm{D}|<10 \%)$, and an increase fragment for an interval of ages 500-900Ma (insert).

B. Th/U ratio for $\mathrm{dZr}$ (ages with $|\mathrm{D}|<10 \%)$. 
Discussion and Interpretation of Obtained Analytical Data

Eight zircons yielded increased ratios of Th/U>1.2 (including №. 80, 214, 177 and 218 with Th/U>1.5) (Figure 4), which may indicate the origin of these zircons from mafic rocks. However, the ages of most of them are highly discordant; these zircons did not appear to be abnormal in other diagrams, their quantity is statistically unrepresentative, so it is not advisable to give a more detailed interpretation of these zircons.

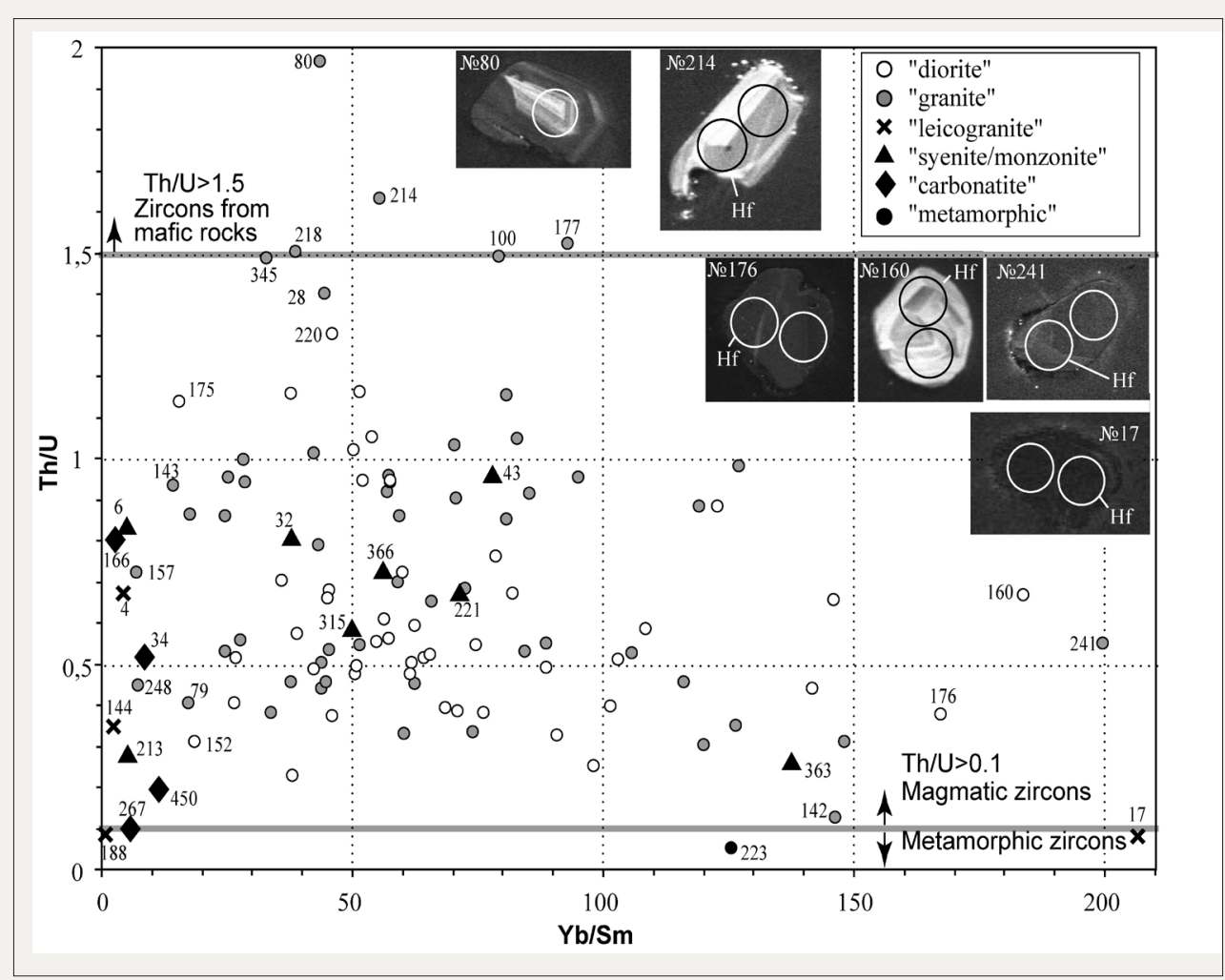

Figure 4: Diagram "Th/U vs $\mathrm{Yb} / \mathrm{Sm}$ " for studied $\mathrm{dZr}$.

Only one zircon (№ 223) yielded Th/U=0.05 which is significantly less than 1 and suggests its metamorphic origin. This zircon has a dark CL-image without zoning that supports its metamorphic nature. Its small size did not allow studying Hfisotopic system. Note that a small population of Early Cambrian zircons from the crystalline rocks of the Kokchetau Massif with $\mathrm{Th} / \mathrm{U}<<0.1$ was reported by Glorie et al. [41]. The origin of these specific zircons is associated with metamorphism in the complexes of high and ultrahigh pressures formed in the subduction zone during the collision of the Kokchetau microcontinent and the Stepnyak volcanic arc. Age of zircon № 223 is $522 \pm 4 \mathrm{Ma}$, although characterized by a rather high discordance $\mathrm{D}=10.5 \%$, but still allows us to make a conclusion about its similarity with the zircons of the above-mentioned population. Four more zircons (№ 17, 142, 188 and 267) yielded Th/U 0.1, which is less certain, but still allows one to assume their metamorphogenic origin or significant metamorphic alteration.

For the remaining $\mathrm{dZr}, \mathrm{Th} / \mathrm{U}>0.2$ and this is the evidence of their most probable magmatic origin. Therefore, for the primary classification of dZr, the CART-algorithm was used (Figure 5). It was predicted that parental rocks for $56 \mathrm{dZr}$ were the most likely "granites", for 47 dZr-"diorites", for 8 dZr-"syenites/ monzonites", for $5 \mathrm{dZr-"leucogranites",} \mathrm{for} 4 \mathrm{dZr-"carbonatites".} \mathrm{Zircons} \mathrm{from}$ "granites" and "diorites" are characterized by similar REE spectra with distinctly manifested $\mathrm{Eu}$ and Ce anomalies (Figure 6), except for only "granitic" dZr № 2, in the spectrum of which Ce anomaly is absent and the contents of light REEs are significantly increased. The classification divide of the CART-algorithm between the dZr from "granite" and "diorite" is $\mathrm{Yb}=501 \mathrm{ppm}$. Additionally dZr from "diorites" are also characterized by higher contents of total REE (Figure 6) and heavy REE (Figure 7) compared to zircons from "granites". Neither in the diagram "Th/U vs age" for the studied dZr with $|\mathrm{D}|>10 \%$ (Figure 3), nor in other classification diagrams (Figure 4-12) any other obvious regularities of the grouping of "granitic" or "dioritic" dZr were revealed.

The most interesting result is the identification of groups of zircon that are specific for their contents of trace-elements. Unlike "granitic" and "dioritic" zircons, which form large groups, specific zircons require individual consideration. In particular, it concerns the verification of the cases when the measured concentrations are near the divide values or the cases of abnormal values of the concentrations of the elements on which the CART-algorithm operates.

All 5 dZr classified as "leucogranitic" (№ 4, 17, 52, 144 and 188) have quite similar dark CL images without visible zoning (Figure 6). 
Grain № 52 yielded increased content P, anomalously high content Ti (2280ppm), all REE and Y (up to 10 times more than the average for zircons), i.e. there is no doubt that a small inclusion of apatite or some other mineral has got into the ablation crater, so the grain № 52 from the further interpretation was excluded. Grains № 4, 144 and 188 are characterized by extremely high contents REE, the absence of Eu minima and very gentle heavy REE spectra (low Yb/ Sm value) (Figure 4). Grains № 17 and 188 yielded lower values of Th/U 0.1 (Figure 3), which, together with the noted features of the REE spectra and other classification parameters, suggests their possible metamorphic origin or alteration.

The one "leucogranitic" dZr (№ 17) only showed concordant age
$(1527 \pm 20 \mathrm{Ma})$, so its Lu-Hf system was also studied $\left(\mathrm{T}_{\mathrm{DM}} \mathrm{C}=2.2 \mathrm{Ga}\right)$. For the remaining 3 "leucogranitic" dZr, the parameters of their Lu-Hf system have not been studied and it is not possible to give a more detailed interpretation of these dZr. In according to the total data, we are inclined to interpret "leucogranitic" dZr not as igneous, but as either primarily metamorphic or subjected to intensive metamorphic and/or hydrothermal altering. Increased contents Ti were fixed in the 3 "leucogranitic" dZr (№ 4, 144 and 188) and in 5 "granitic" zircons (№ 37, 159, 340, 345 and 448) (Figure 6). However, for these zircons neither in imaging, nor in classification parameters, it was possible to identify similarities that would allow them to be treated as a separate specific population.

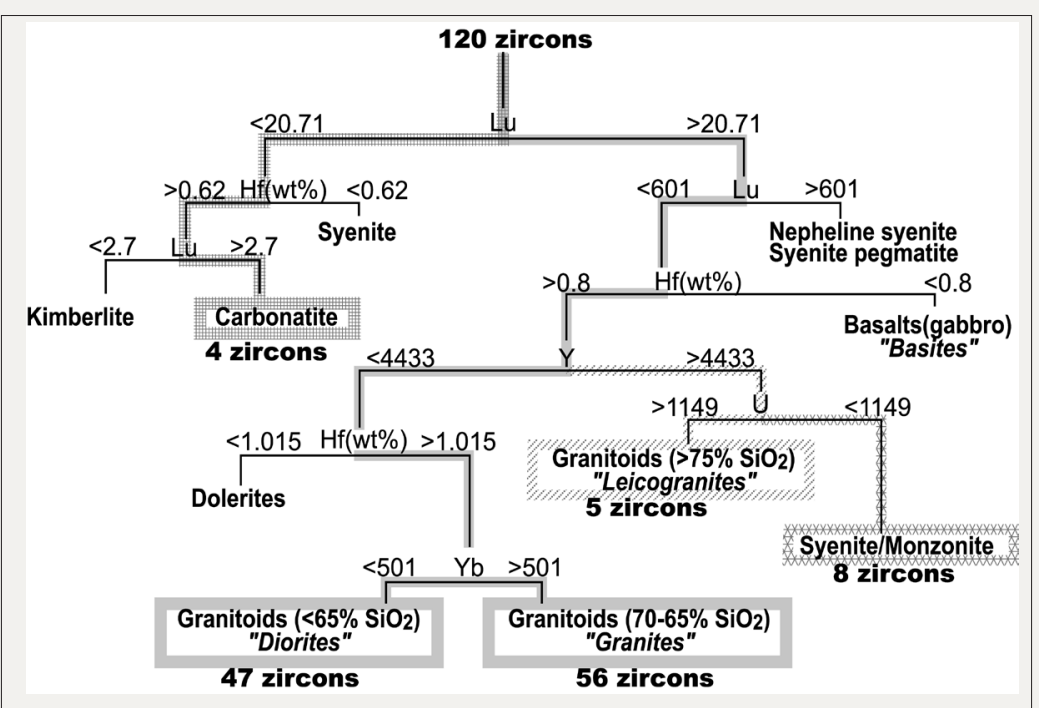

Figure 5: The classification tree of the CART-algorithm used to predict the type of parent rocks of the studied dZr from the sample K15-501. Gray and raster lines mark paths along the tree, according to which the type of parent rocks was classified for $56 \mathrm{dZr}$ as "granite", for $47 \mathrm{dZr}$ as "diorite", for $8 \mathrm{dZr}$ as "syenite/monzonite", for $4 \mathrm{dZr}$ as "carbonatite", and for $5 \mathrm{dZr}$ - as "leucogranite".

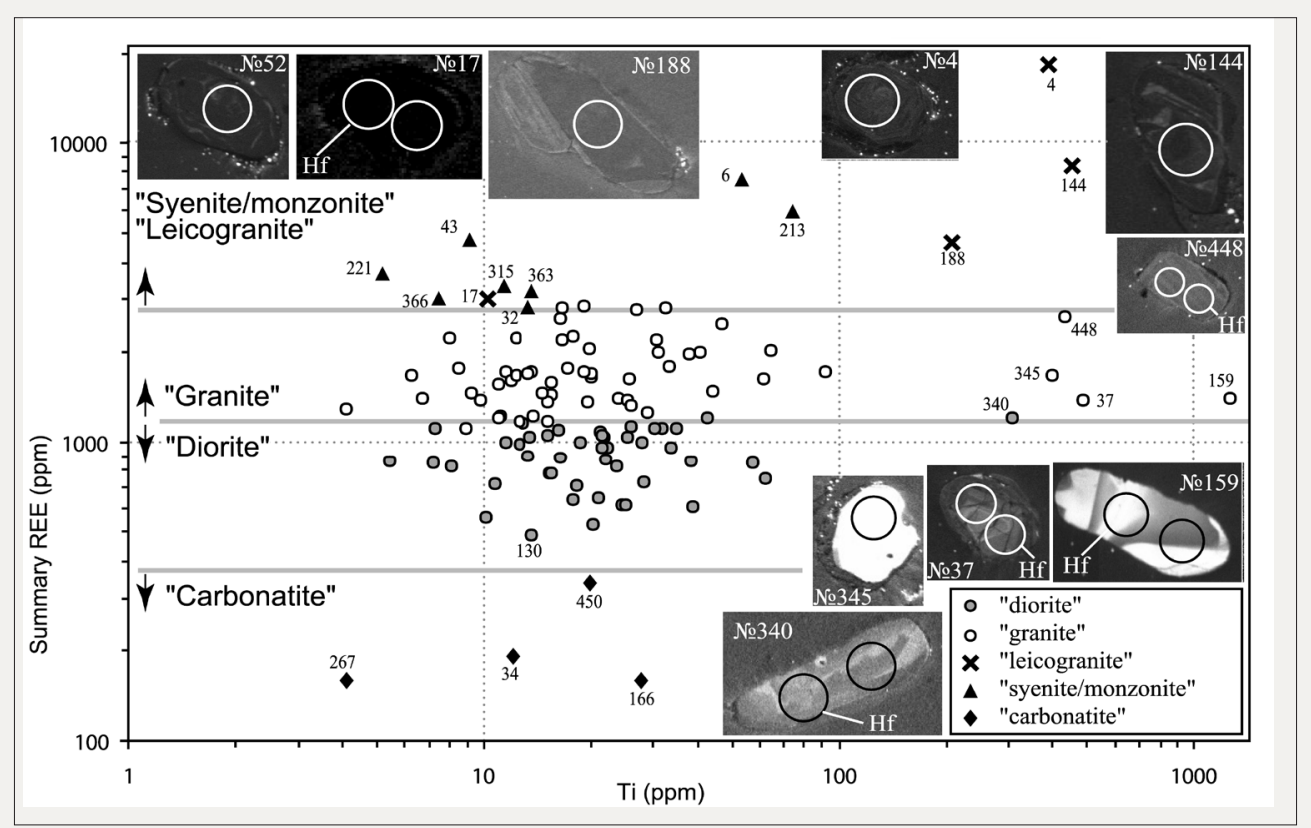

Figure 6: Diagram "Total content of REE vs Ti” in dZr. 


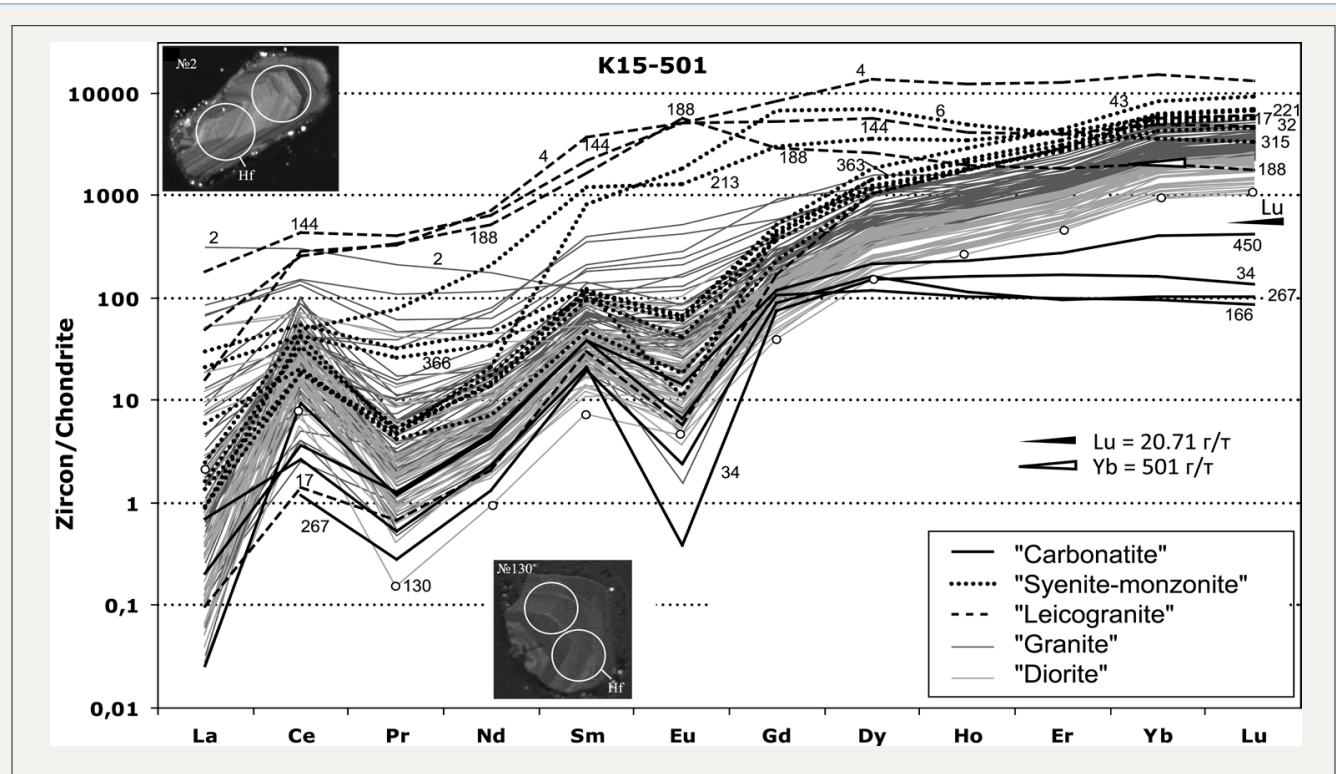

Figure 7: Chondrite-normalized contents of REE in dZr.

To separate magmatic zircons from kimberlites/carbonatites/ syenites from zircons from other types of parent rocks, the most statistically effective criterion is the content $\mathrm{Lu}$ in zircon below the threshold value of $20.71 \mathrm{ppm}$. Reduced REE contents together with moderate concentrations of $\mathrm{Hf}(>0.62 \%)$ and $2.7 \mathrm{ppm}<\mathrm{Lu}<20.71$ ppm in the CART-algorithm are typomorphic signs of zircon from "carbonatite" (Figure 5). At low content of Lu in zircon, the contents of heavy REEs are usually low too, and the summary contents of REEs in this zircon turn out to be lower. Indeed, the total contents of REEs (Figure 6) for all zircons classified as "carbonatitic" (№ 34, 166, 267 and 450), are less than 300ppm. Zircon № 130 yielded very low contents of light REEs (Figure 7), which forced us to test this dZr as potentially "carbonatitic". But the content of $\mathrm{Lu}(43 \mathrm{ppm})$, and the total content of REE (487ppm) is much higher than the classification thresholds for "carbonatitic" zircons.

In the classification diagrams, "carbonatitic" dZr are also confidently separated from the "dioritic" and "granitic" ones by low $\mathrm{Yb} / \mathrm{Sm}$ ratios-gently sloping spectra in the heavy REE (Figure 4), low Y contents (Figure 8), high $\mathrm{U} / \mathrm{Nb}$ ratios (Figure 11), as well as an increased content of Hf (Figure 1 \& Figure 8) and a lower content of Ta and $\mathrm{Nb}$ (Figure 9). Note that these parameters have not been used explicitly for the dZr classification using the CART-algorithm. All 4 "carbonatitic" dZr have a CLI characteristic for zircons from carbonatites [38] and close ages (Figure 2). Moreover, they form a discord, with an upper intersection with a concordia of about 2.0Ga (Figure 2). Three of these dZr, having close values of $\varepsilon_{\mathrm{HP}}$, form a compact group on the "Diagram $\varepsilon_{\mathrm{Hf}}$ " (Figure 13). The value of $\varepsilon_{\mathrm{Hf}}$ is about +5 , indicates that the substrate from which the magmas, parental to these zircons were melted, was juvenile (contained a small amount of isotope-mature material). However, one dZr (№ 267) yielded a slightly negative value of $\varepsilon_{\mathrm{Hf}}$, which indicates that the magma-generating substrate contained a noticeable addition of isotope-mature crustal material. This $\mathrm{dZr}$ is characterized also by a lower value of $\mathrm{Th} / \mathrm{U} \sim 0.1$, i.e. perhaps this grain was under went metamorphic processing. Thus, in the sample K15-501, a provenance-signal from a local short-lived (ultra)alkaline magmatic source was recorded. Its activity was manifested $\sim 2.0 \mathrm{Ga}$. Most of the mantle (juvenile) magmas crystallized without contamination with crustal material, and only possibly minimal interaction was with the ancient sialic isotope-mature substance, which is fixed by a slightly negative $\varepsilon_{\mathrm{Hf}}$ (grain №. 267). The fact that a group of $4 \mathrm{dZr}$ with the same ages, similar contents of trace-elements and CL-images makes the interpretation them as "carbonatitic" zircons much more reliable than it would be for a single dZr.

When studying dZr from sandstones of Ai Formation (the lowest part of Riphean Group) of the Bashkir Uplift located in the Western Southern Urals [6,16,42], a zircon population of "carbonatitic" grains was revealed for the first time, with an age of grains 2.05Ga. "Carbonatitic" zircons from sample K15-501 both by age, both by the content of trace-elements, and by Hf-isotopic characteristics are almost identical to "carbonatitic" zircons from sandstones Ai Formation of the Bashkir uplift. According to the data given in $[43,44]$, zircons from crystalline rocks selected from different blocks of the Early Precambrian Taratash complex of the Southern Urals yielded ages $2055 \pm 45,2052 \pm 41,2020 \pm 17$ and $2044 \pm 4$ Ma (the upper intersections of concordia and discordia). For the eastern part of Sarmatia, [45] reported U-Pb ages of $2047 \pm 17,2040 \pm 162050 \pm 16$ Ma for some rocks and [46] reported SIMS zircon crystallizat-ion ages for the granitoids lying within the range of 2050-2070Ma. However, till now the Precambrian carbonatites have been described neither in the Taratash complex, nor in the south eastern part of the EEP. Therefore, the question of the source of the "carbonatitic" zircons is open but has the prospect of being resolved as more data on the crystalline rocks of EEP and Southern Urals will have been accumulated. In this connection, we mention that the ages of "carbonatitic" dZr from sample K15-501 and sandstones from Ai Formation (lower part of Riphean Group) of the Bashkir uplift correlate well with ages of carbonatites from 
such known complexes as Phalaborwa, Bushveld, Kaapval Craton ( 2.06Ga, [47]), Tiksheozero, Karelia, the Baltic Shield ( 2.0Ga, [48]), Bayan Obo, China ( 2.07Ga, [39]), and others see the recent review in Rukhlov et al. [49].

In sample K15-501, 8 dZr (№ 6,32,43,213, 221,315, 363 and 366) have been classified as zircons originating from "syenite/ monzonite". The "syenite/monzonite" dZr clearly differ from other dZr according to the increased Y content (Figure 8) and total contents REE (Figure 6). The spectra of "syenite/monzonite" $\mathrm{dZr}$ are very variable and some of them differ from the spectra of "granitoid" dZr with only slightly increased REE contents. For them, in general, the increased $\mathrm{Nb}$ and Ta contents (Figure 9) and weakly manifested Ce anomalies are fixed (Figure 10).

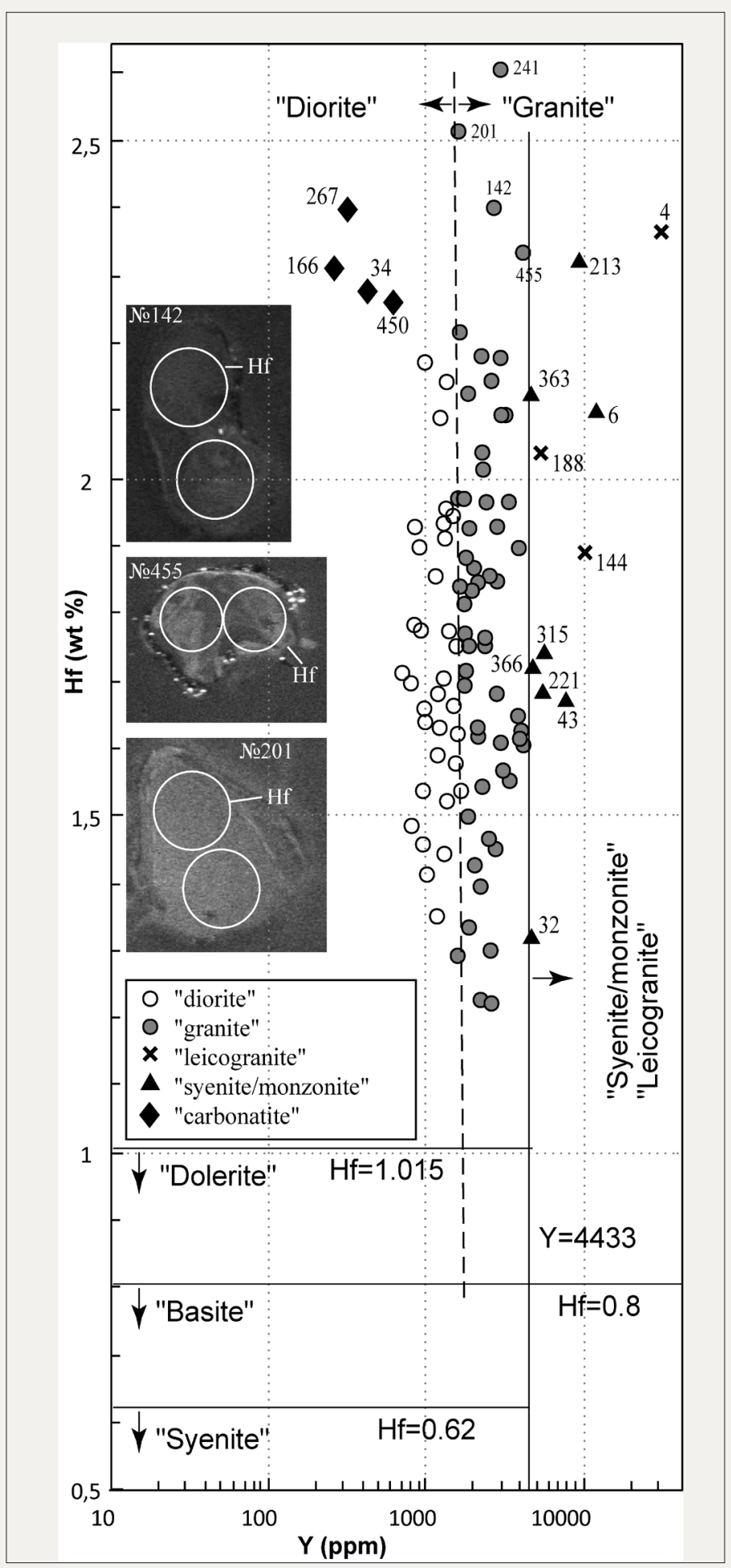

Figure 8: Diagram "Contents Hf vs $\mathrm{Y}$ " in $\mathrm{dZr}$. 


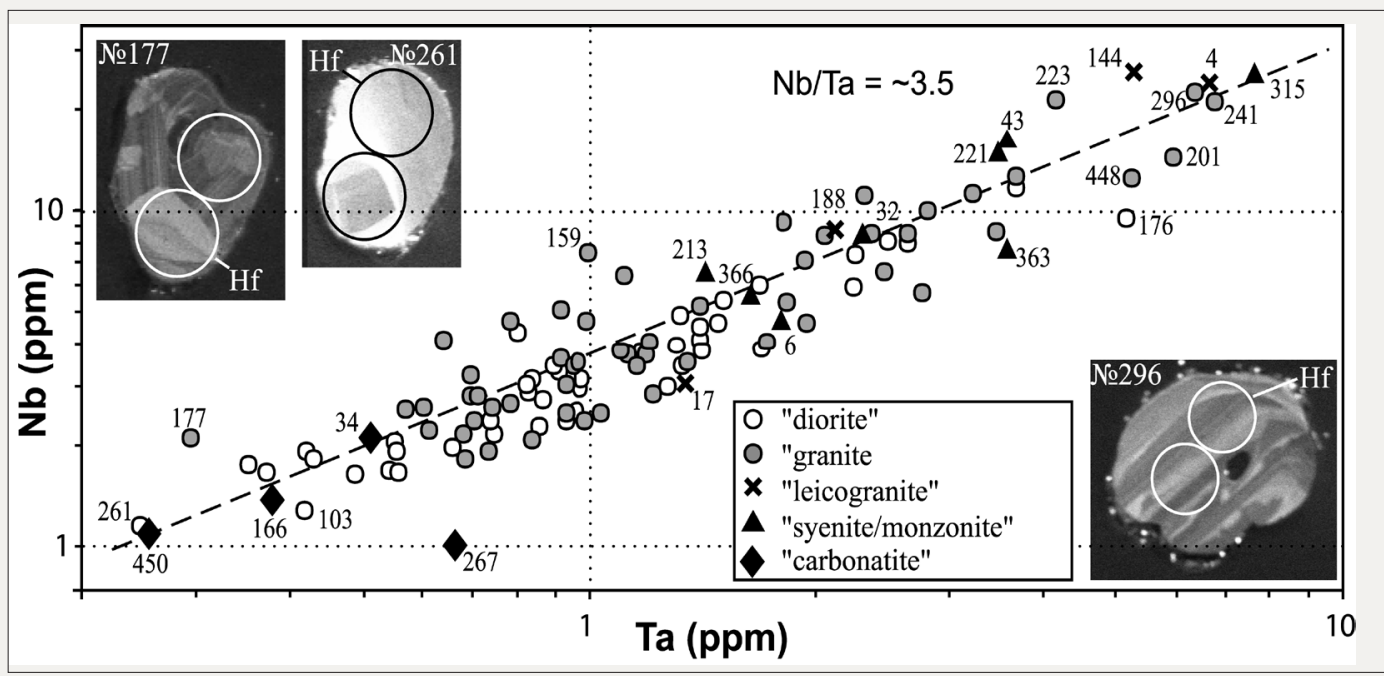

Figure 9: Diagrams "Contents $\mathrm{Nb}$ vs $\mathrm{Ta}$ " in $\mathrm{dZr}$.

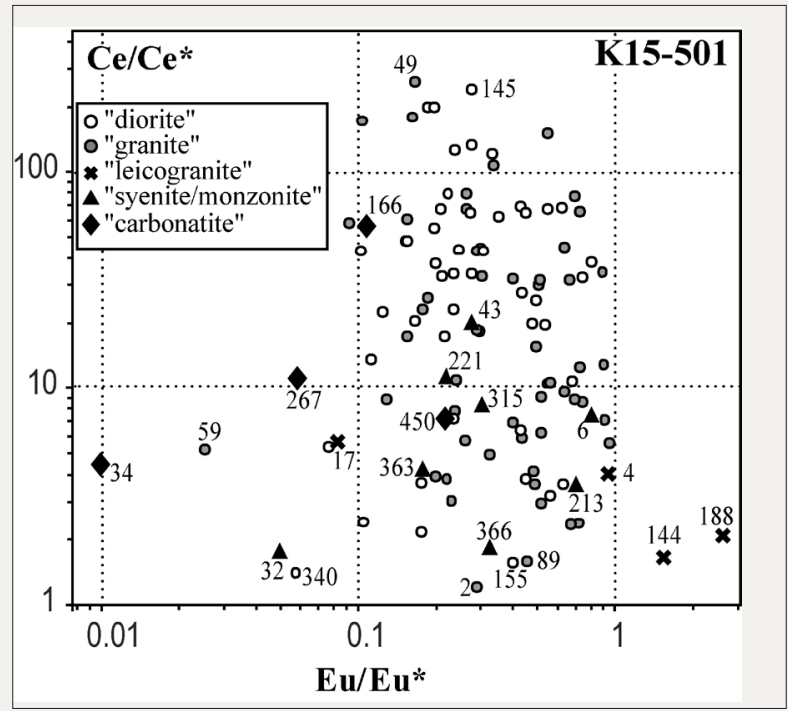

Figure 10: Diagram "Ce/Ce* vs $\mathrm{Eu} / \mathrm{Eu}^{*}$ " in $\mathrm{dZr}$.

For all "syenite/monzonite" dZr from sample K15-501 Th/U>1. This is considered a sign of the magmatic genesis of these zircons. However, their CL images have characteristics of zircons that have been undergone by metamorphic processing. All these grains have metamorphic rims, while grains № 32,43,213 and 315 also have metamorphic-appearance cores. In cores of grains № 6, 221, 363 and 366, the cores are more likely to be of magmatic origin (Figure 2). In this connection, we note that high contents of $Y$ and REE were observed in zircons from hydrothermal formations [50] and in the rims of hydrothermally processed zircons. Therefore, it cannot be completely ruled out that the grains classified by us as "syenite/ monzonite" zircons are actually hydrothermal in nature and/or have been undergone hydrothermal processing. In this connection, the increased Y content in zircons № 52 and 144, classified as "leucogranitic" ones, may also indicate a hydrothermal effect on them.

Grains № 315 and 213 have yielded concordant ages of $1234 \pm 25$ and $1541 \pm 43 \mathrm{Ma}$, correspondently. For the remaining 6 "syenite/ monzonite" zircons, the ages are close and within an interval from 527 to $618 \mathrm{Ma}$, although 3 of them are characterized by rather strongly discordant. Grain № 43 is so small that there is no room for a second crater to get the Hf isotopic characteristics. For grains № 32 and 221 , despite the high discordance of the U-Pb age $(13 \%$ and $16 \%$, respectively), the Lu-Hf system was studied. The figurative points of 4 grains for which the Hf-characteristics were obtained, on the "Diagram $\varepsilon_{\mathrm{Hf}}$ " form a compact Cluster SM. It cannot be said with certainty that "a group of zircons=Cluster SM + zircon № 315" characterize a single source, but if it is, the figurative points of this group form a line - "Trend SM", ideally (given the accuracy of U-Pb ages and estimates of the parameter $\varepsilon_{\mathrm{Hf}}$ ) fit with a line of evolution of the average continental crust with an age of 1.6Ga (Figure 13).

If zircons of "Trend SM" group originated from one source, then they represent a provenance signal from a long-acting local alkaline source of syenite-monzonite type, magmatism in which started at least $\sim 1.2 \mathrm{Ga}$. At that time, the magmas were juvenile (positive $\varepsilon_{\mathrm{Hf}}$ ). Then this magma chamber was activated at $\sim 600 \mathrm{Ma}$. Because its 
Hf-isotopic features have evolved according to age and based on trace-element content in zircons, there was no fractionation and/ or crustal contamination of magma. Unfortunately, the quantity of "syenite/monzonite" zircons is not enough to statistically reliably support the above conclusion. Never the-less, it can be concluded that in the sample K15-501, a provenance signal from a local specific source of "syenite/monzonite" type was fixed. In the Western Urals, magmatic complexes with similar ages of the "syenite-monzonite" zircons from the K15-501 sample are not yet known (Figure 13).

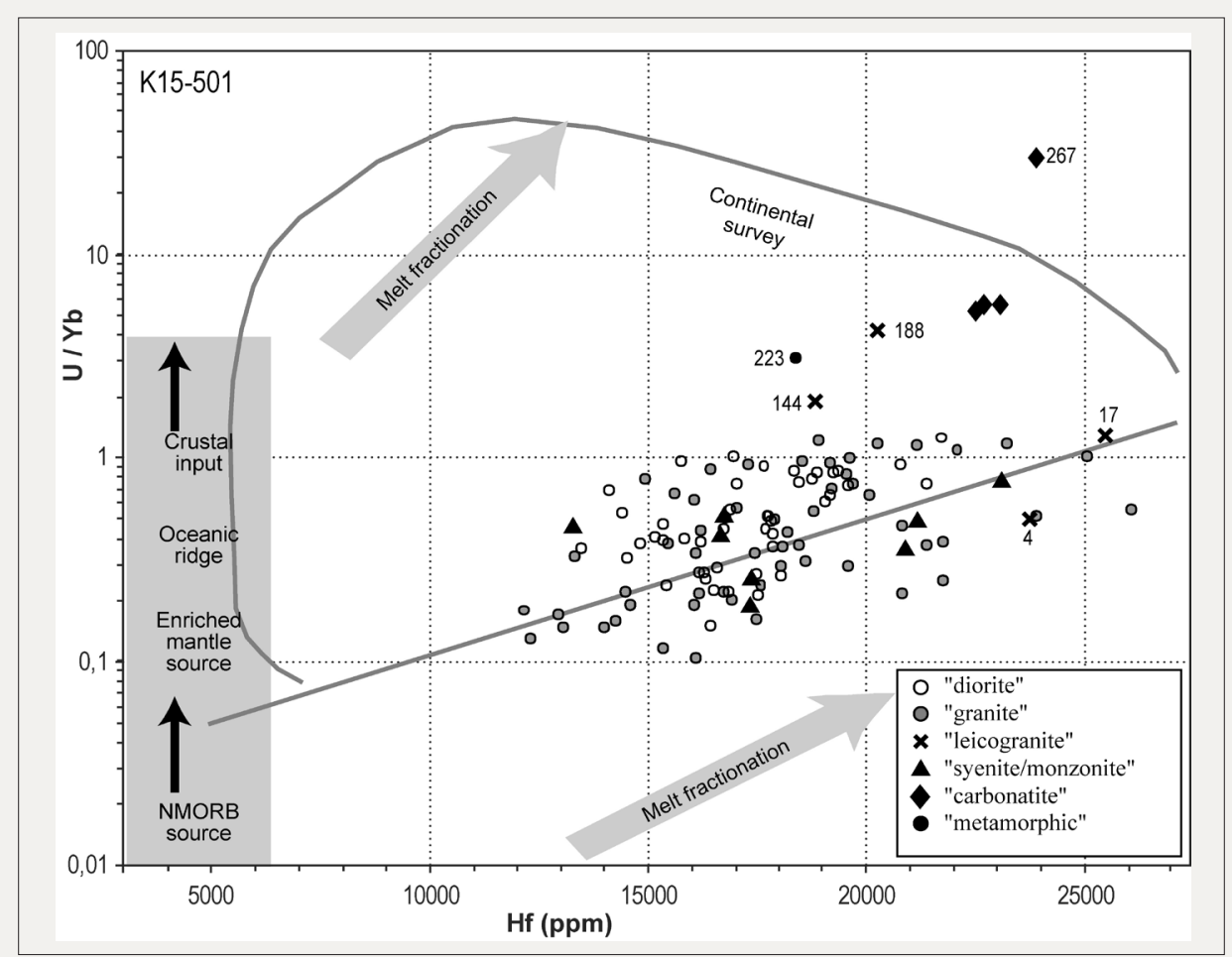

Figure 11: Diagram "U/Yb vs Hf" in dZr. Field Continental survey", arrows and inscriptions after [Grimes et al., 2015, Fig. 2].

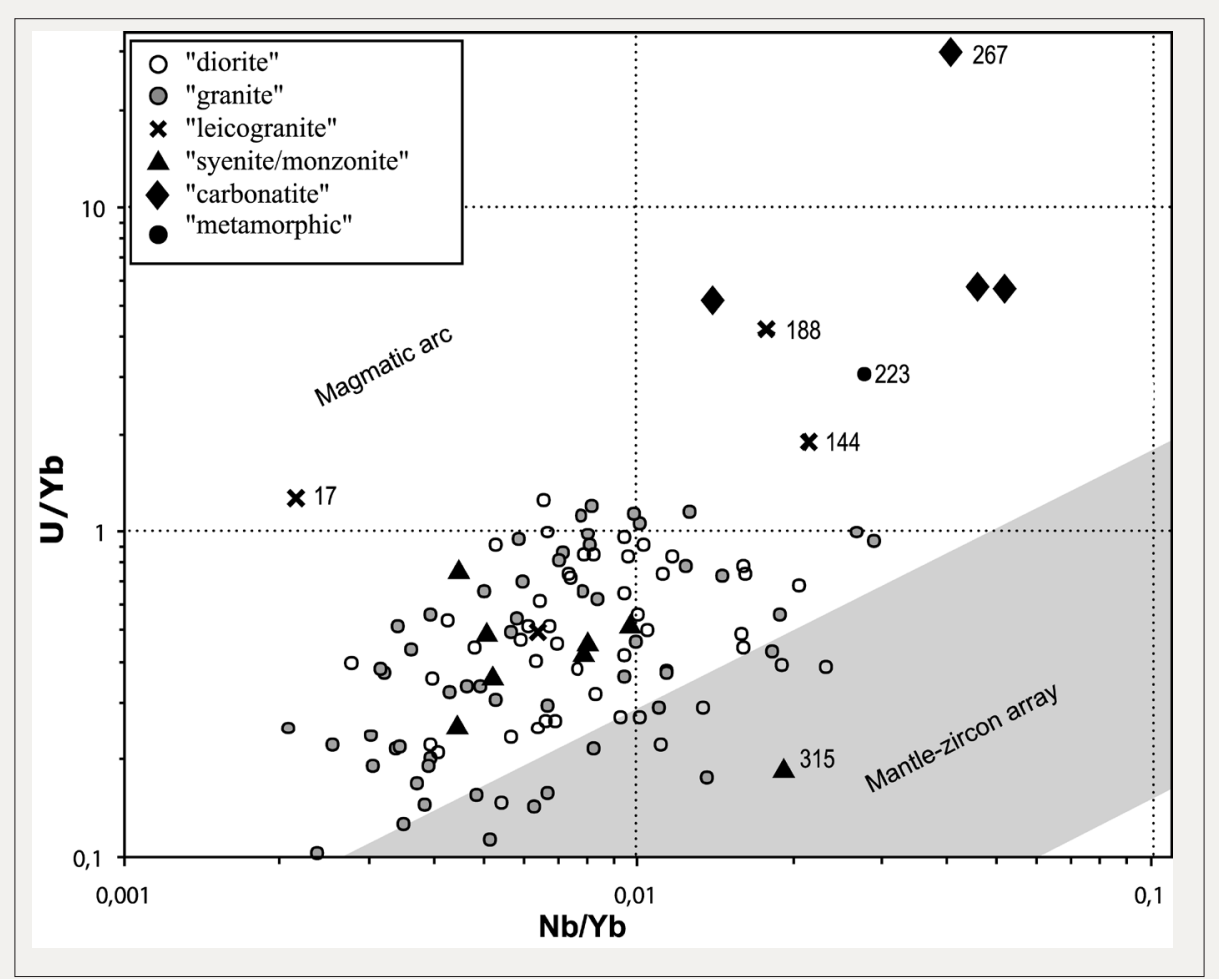

Figure 12: Diagram of the ratios "U/Yb vs Nb/Yb" in dZr. Fields "Magmatic arc" and "Mantle-zircon array" after [Grimes et al., 2015, Fig. 6C] 
On the diagram "U/Yb vs Hf" (Figure 11), which makes it possible to distinguish zircons from oceanic basalts $(\mathrm{U} / \mathrm{Yb}<0.1)$ from zircons from rocks of continental genesis, slightly more than a third of the figurative points $(n=45)$ characterizing zircons from the sample K15-501, goes out of the field, characteristic of zircons from magmatic rocks of "continental origin". At the same time, the values of $U / Y b<0.1$, which would allow us to speak with a high degree of certainty about ocean basalts as sources of at least a part of the zircons from sample K15-501, were not fixed. Note, that the figurative points of "carbonatitic" dZr from the sample K15-501 are confidently located in the field of zircons from magmatic rocks of "continental origin". These zircons are characterized by high (and for zircon №. 267-very high) values of U/Yb. The high values of U/ Yb for "metamorphic" zircon № 223 and "leucogranitic" zircons № 144 and 188 is an indirect argument indicating either a high degree of melt fractionation, or a metamorphic effect on zircons № 144 and 188. The figurative points of both "syenite/monzonite", and "leucogranite" dZr are located within the field of zircons, characteristic of igneous rocks of "continental origin". In the diagram "U/Yb vs Nb/Yb" (Figure 12), which makes it possible to distinguish zircons from mantle (juvenile) rocks from zircons from rocks of magmatic arcs, 15 figurative points fall into the field of zircons, characteristic of rocks of mantle origin. It is interesting to note that all figurative points of the "syenite/ monzonite" $\mathrm{dZr}$ from Cluster SM, having the negative $\varepsilon_{\mathrm{Hf}}$ are localized in the "magmatic arc field", but the figurative point of grain № 315, having essentially positive value of $\varepsilon \mathrm{Hf}$ (an indication of the mantle origin of the magma-generating substrate) is located within "mantle zircons" field.

Comparison of the ages, geochemical, and isotope-geochemical characteristics of dZr from sample K15-501 with known data on the composition, age and model ages of the crystalline complexes of the Western Urals and the basement of the Volga-Ural part of EEP (Figure 13) showed the following.

1. Several figurative points of dZr from the sample K15501 showed a coincidence with the age of intrusive rocks of the Berdyaush massif. Note that the positive values of $\varepsilon \mathrm{Hf}=4.6 \pm 1.0$ for zircons from the gabbro, but negative values $\varepsilon \mathrm{H}$ of $-5.3 \pm 0.7,-6.0 \pm 0.9$ and $-7.6 \pm 1.4$ for zircons from nepheline syenites, granite-rapakivi and quartz syenite-diorites, respectively, are fixed (Ronkin et al., 2015). The simultaneous occurrence of basites with substantially positive $\varepsilon H f$ and silicic rocks with significantly negative $\varepsilon H f$ is characteristic for bimodal series. Such rocks form associations and therefore in the products of their erosion there should be zircons with both positive and negative eHf. Considering that zircons are much rarer in rocks of the basic composition than in silicic rocks, the probability of detection dZr from bimodal complexes with negative $\varepsilon H f$ in erosion products is much higher. However, among the $\mathrm{dZr}$ from sample K15-501, zircons with negative $\varepsilon \mathrm{Hf}$ and ages comparable with the age of the Berdyaush intrusive massif were not revealed. Therefore, it is a low probability that Berdyaush complex was a source for the dZr of the K15-501 sample.

2. No figurative point of dZr from sample K15-501 showed significant coincidences with the fields of the Tashlyar and
Aktanysh complexes, as well as the Kolyvan enderbites involved in the structure of the basement of the Volga-Ural part of EEP. Two figurative points fell in the field of Bak- 2 and one in the field of Bak1 , which characterize the quartz diorite of the Bakaly block. Note that the predicted type of parent rocks of these $3 \mathrm{dZr}$ is "diorites", which coincides with the type of rocks of the Bakaly block. However, this is insufficient statistics to identify quartz diorites of the Bakaly block as a local source.

3. Six figurative points of $\mathrm{dZr}$ from sample K15-501 fell into the field of isotopic parameters of the rocks of the southern part of the Volga-Sarmatian collision orogen (hereinafter referred to as the "VSO-field").In addition, the figurative points of the three "carbonatitic" dZr and four "dioritic" dZr are close to the "VSOfield". On the "Diagram $\varepsilon_{\mathrm{Hf}}$ " (Figure 13), the "VSO-field" is located in the upper part of the area, which is formed by figurative points with a range of changes in the values of $\varepsilon \mathrm{Hf}$ from the maximum positive (line DM) to substantially negative values corresponding to the model ages of the magma-generating substrate 2.5-3.5Ga and is indicative of the recycling of the Neoarchean and Mesoarchean crust. Such series are a sign of mixing juvenile and isotope-mature materials, which can occur in long-acting volcanic arcs on the continental margins or in collision orogens.

A large volume of geochronological dating of crystalline rocks involved in the structure of relics of the Paleoproterozoic orogens has been accumulated [51]. Most of these orogens are composed of complexes with ages <2.0Ga. Within EEP only for VSO [52] and Taratash Orogen [43], which are the oldest of these orogens and closest to the Sol-Iletsk arch, the ages of 2.1-2.0Ga have been obtained. Since Early Proterozoic grains with ages of 2.15-2.0Ga have been fixed in sample K15-501, this can be the reason to consider VSO and Taratash Orogens their most probable source.

\section{Paleogeographic Interpretation of the Obtained Data}

The Archean proto-cratons Volga-Uralia, Sarmatia, Kola and Karelia are distinguished in the basement of the EEP with ages of 2.5-3.5Ga. They were sutured by the Late Proterozoic orogens (Volgo-Sarmatian, Lapland-Kola, Volyn-Middle-Russian) with ages 1.65-2.2Ga [53] (Figure 1). If clastic material from EEP was transported in the Ordovician Sol-Iletsk sedimentary basin (hereinafter referred to as S-Ib) on the south eastern edge of EEP, then the corresponding isotopic parameters of $\mathrm{dZr}$ from the sample K15-501 can be expected. Indeed, a comparison of the isotopic parameters of dZr from sample K15-501 with known analogous characteristics of the complexes of the south eastern part of EEP (Figure 13) shows that the primary sources of Early Precambrian dZr in the sample K15-501 with a high degree of probability might be Late Proterozoic VSO and Taratash Orogen and Archean complexes of the of Volga-Uralia basement.

Specific "carbonatite" zircons identified in the sample K15-501 have ages and Hf-isotopic characteristics almost identical to dZr from the sandstones of the Ai Formation of the Bashkir Uplift [16]. This indicate that the erosional products of the sedimentary strata of Riphean Group of the Bashkir Uplift might also been recycled in S-Ib. However, among the dZr from samples K15-501, numerous 
zircons with ages younger 1.65 Ga have been fixed. Such ages are absolutely atypical for the crystalline complexes of the southeastern part of EEP basement. The primary sources of these dZr might be located either within parts of EEP very remote from S-Ib, or outside the EEP.

For example, within the Fennoscandia, Mesoproterozoic granites rapakivi and paragenetically associated migmatites are widely developed [54]. Sveco-Norvegian domain is composed mainly of the Mesoproterozoic (Danopolonian) and Early Neoproterozoic granite-metamorphic complexes [53]. The Volyn volcanic province in the southwestern part of Sarmatia composes of Late Neoproterozoic (Ediacaran) basaltoids, volcanogenic-tuffo genic formations and acid rocks [55].

In the upper part of the Figure 13, the bars show the age intervals for the EEP and Western Southern Urals complexes: T-granitoids and meta-morphites of the Taratash complex; $\mathrm{N}$-alkaline basaltoids of the Navyshsky complex; bMs-bimodal volcanics of the Mashak suite; Bm-granitoids and syenites of the Berdyaushsky massif (G-gabbro,
NS-nepheline syenites, GR-granites-rapakivi, QS-quartz syenodiorites); M-granitoids and gabbroids of the Mazarinsky magmatic areal; VSO-complexes of the Volga-Sarmatian orogen, which sutured the Volga-Uralia and Sarmatia proto-cratons; K, KN, NU, O-plutons and rapakivi-like granites-Korosten, Korsun-Novomirgorod, NovoUkrainian, October plutons; LKO-complexes of the Lapland-Kola orogen, sutured Kola and Karelia proto-cratons; SF-complexes of the Sveco-Fennian domain; VMRO-complexes of Volyn-MiddleRussian orogen, sutured Fennoscandia and Volgo-Sarmatia; SNcomplexes of the Sveco-Norwegian domain; Gren-complexes of the Sveco-Norwegian (Grenville) orogen, which sutured the ProtoBaltica, Proto-Laurentia and Amazonia in the process of assembling Rodinia; R, V, S-plutons and rapakivi-like granites-Riga, Vyborg and Salmi plutons; pU-TO-complexes of the Proto-Uralide-Timanide orogen, which sutured the Baltica and Arctida; VVP - complexes of the Volyn volcanic province; cSTp- the basement Cadomides of the Scythian-Turanian plate; CGO-Greenland Caledonian orogen, which sutured Arctic Europe and Laurentia.

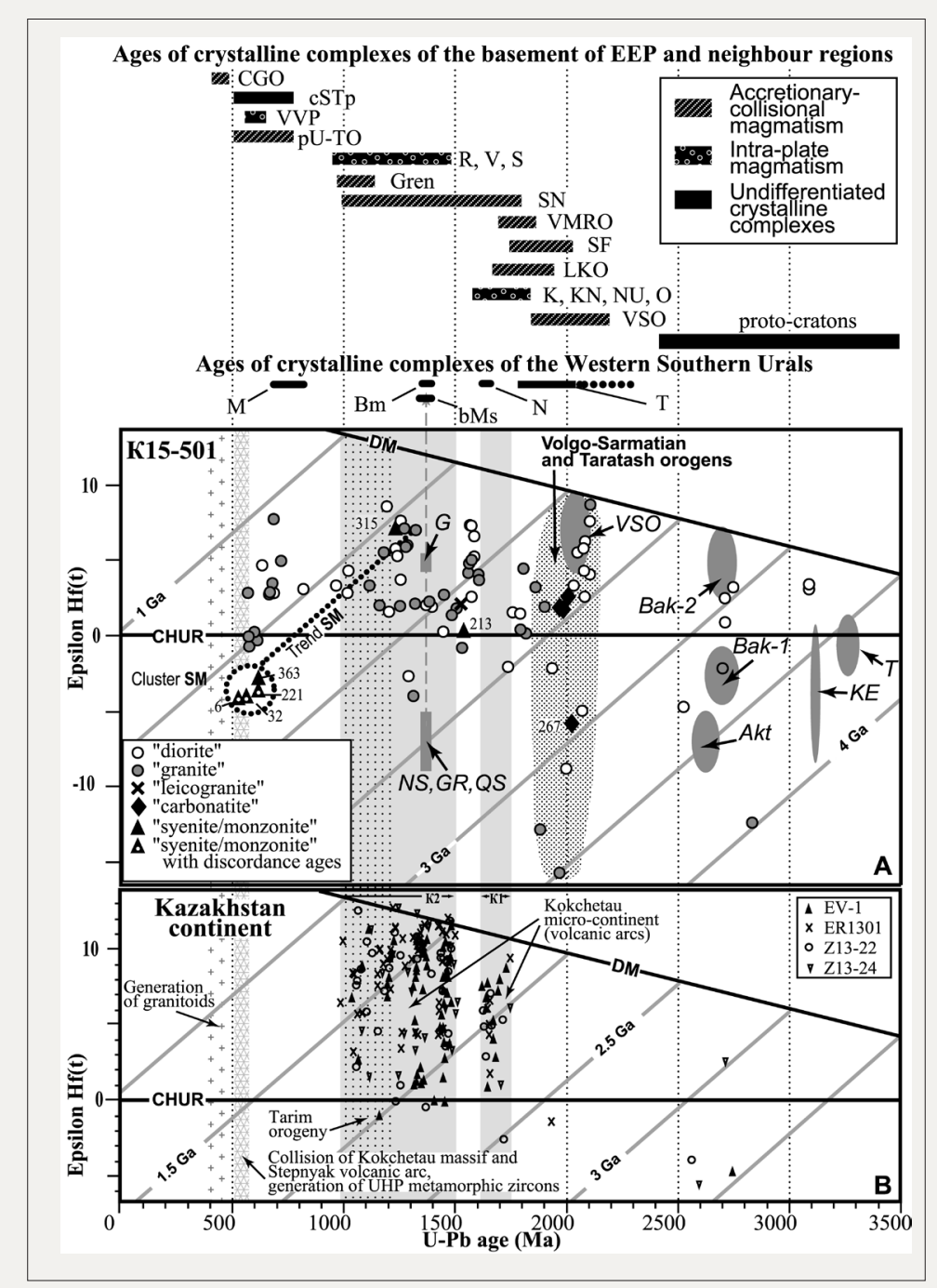

Figure 13: Isotope-geochemical characteristics of $\mathrm{dZr}$ from sample $\mathrm{K} 15-501$ and their comparison with known analogous parameters of complexes of EEP and adjacent areas. 
Relicts of the Proto-Uralide-Timanide orogen, in the structure of which Late Neoproterozoic-Cambrian granitoids and metamorphites are widely represented [56], are located in the northeastern periphery of EEP. The small-volume crystalline complexes with ages $<1.65 \mathrm{Ga}$ are known in the Western Urals, as well as in some Mesoproterozoic-Early Neoproterozoic (Riphean) aulacogenes in the south-eastern part the EEP (Gusikhin complex in the Pachelma aulacogene, etc.) (Figure 13). The erosional products of all these rocks might be recycled in the S-Ib by well-developed long river systems. However, it cannot be ruled out that the primary sources for dZr younger1.65Ga in the K15-501 sample were located outside the EEP. Various crustal blocks composed of crystalline complexes with Mesoproterozoic, Neoproterozoic and Cambrian ages might be located near the Baltica (Early Precambrian skeleton of EEP) during some time intervals and their erosional products could be accumulated into sedimentary basins located on the edge of Baltica, and then, by recycling to enter the S-Ib.

The previous works have showed that in the Riphean Group of the Bashkir uplift (Western Southern Urals), dZr with ages older 1.65 Ga are fixed $[42,57,58]$. It corresponds to the source rocks composed only of Early Precambrian crystalline complexes and consistent with the transportation of clastics into the Mesoproterozoic-Early Neoproterozoic (Riphean)basin of the Western Southern Urals from the Volga-Uralian part of EEP. But at higher stratigraphic levels, into the Latest Neoproterozoic to Early Cambrian Ash Group [59,60] and Ordovician [61], the numerous dZr with Mesoproterozoic and Neoproterozoic ages, atypical for crystalline basement of VolgaUralian part of EEP were fixed. The same as it is in sample K15501. Their potential primary sources might be complexes of crustal blocks, which now form the basement of the Scythian-Turanian plate or the Paleozoides of Central Kazakhstan (the basement of the Epi-Paleozoic Kazakhstan continent).

A representative volume of geochronological data has already been accumulated for the basement of the Epi-Paleozoic Kazakhstan continent, which allows us to reconstruct the main stages of the formation of its heterogeneous continental crust [62]. In accordance with these data, the skeleton of the Kokchetau micro continent, which compose a core part of the basement of the Epi-Paleozoic Kazakhstan continent, was formed from the juvenile material of Late Proterozoic and Mesoproterozoic intraoceanic arcs. The earliest recorded magmatic episode (K1) is dated as $1.85-1.65 \mathrm{Ga}$, the next episode (K2) lasted at least from 1.5 to $1.0 \mathrm{Ga}$. Its final phases of 1.2-1.0 Ga are known as the Tarim orogeny, relicts of which are preserved in Northern Kazakhstan (the North-Kazakhstan tectonic zone). During this tectonic phase, the assembling of the Kazakhstan continent as a large heterogeneous continental crust block and consolidation of its basement was the most likely realized.

The study of detrital zircons from the MesoproterozoicEarly Neoproterozoic (Riphean)cover of the Kokchetau Massif (4 samples) [63] revealed several Archean dZr, a small group of Late Proterozoic dZr (correlated with the K1 episode) and a dominant population of Mesoproterozoic zircons (correlated with the K2 episode) (Figure 13). In the Late Neoproterozoic, the Kokchetau
Massif collided with the Stepnyak volcanic arc, then the UHP complexes of the subduction zone were exhumed and became a source of specific metamorphic zircons with abnormally low Th/U ratio [41]. Later, extensive areas of the Kazakhstan continent were intruded by Paleozoic granitoids $[62,64]$.

A comparison of the Hf-isotope characteristics of $\mathrm{dZr}$ from the Mesoproterozoic-Early Neoproterozoic (Riphean)cover of the Kokchetau Massif and the Mesoproterozoic dZr from the K15-501 sample shows the following differences:

1. In the $\mathrm{K} 2$ group, $\mathrm{dZr}$ with very high positive $\varepsilon_{\mathrm{Hf}}$ (including $\left.\varepsilon_{\mathrm{Hf}} 10-13\right)$ are fixed, i.e. corresponding to DM, however, dZr with $\varepsilon_{\mathrm{Hf}}>7$ in sample K15-501 are not fixed;

2. In sample K15-501, no dZr was found with the ages corresponding to the age of the dZr of the K1 group;

3. In K15-501 sample, numerous dZr were revealed with ages of 1.5-1.6Ga, which are absent in Kazakhstan samples.

Thus, the absolute discrepancy between the $\mathrm{dZr}$ characteristics from group $\mathrm{K} 1$ and a partial coincidence only of the dZr characteristics from group K2 (Kazakhstan samples) with characteristics of dZr from sample K15-501 allows Baltica adjoins to one of the volcanic arcs of the $\mathrm{K} 2$ episode during some time in Neoproterozoic. The erosional products of this volcanic arc could be transported into a Late Neoproterozoic basin on the edge of Baltica and then be recycled into the S-Ib. Later, the relics of this volcanic arc became a part of the basement of Kokchetau microcontinent. A strong interaction of the entire Kazakhstan continent with Baltica in Neoproterozoic is unlikely. This would inevitably lead to the erosion of cover of the Kazakhstan continent, which contains dZr sourced from crystalline complexes of episodes both $\mathrm{K} 1$, and $\mathrm{K} 2$, including those with Hf-isotopic parameters comparable to DM. There are no such dZr in the sample K15-501. There have been no geochronological data on the deep-buried complexes of the basement of the Scythian-Turanian plate. The latter is interpreted as a belt of Cadomian terranes that extends from Europe along the southern periphery of the EEP into the Central Asian Orogenic Belt based on geophysical data and indirect correlations only.

\section{Conclusion}

To obtain the characteristics of the sources for Ordovician terrigenous rocks of the Sol-Iletsk arch located at the south-eastern edge of EEP, 120 detrital zircons from sandstones reached by borehole Ordovician-2 (sample K15-501) were comprehensively (U-Pb age, Hf-isotope and trace-elements) studied. The primary sources of Early Precambrian dZr from sample K15-501 were most likely sourced from the crystalline complexes of the Late Proterozoic Volgo-Sarmatian and Taratash orogens and Archean Volga-Uralia basement. However, for numerous zircons with ages younger $1.65 \mathrm{Ga}$, it is not possible presently to unambiguously identify primary sources. Crystalline complexes with such ages are absolutely atypical for the south-eastern part of the EEP, but they occurred within parts EEP very remote from Sol-lletsk arch and beyond EEP. 
The contents of the trace-elements allowed us to predict the type of parental rocks of zircons. The parent rocks for $56 \mathrm{dZr}$ were most likely "granites", for $47 \mathrm{dZr}$-"diorites", for $4 \mathrm{dZr-"carbonatites",}$ for $8 \mathrm{dZr}$-"syenites/monzonites", and for $5 \mathrm{dZr}$-"leucogranites". "Carbonatitic" zircons from sample K15-501 both by age, both by the content of trace-elements, and by Hf-isotopic characteristics are almost identical to "carbonatitic" zircons from sandstones Ai Formation (the lowest part of Riphean Group) of the Bashkir uplift (Western Southern Urals). Thus, a provenance-signal from a local (ultra)alkaline magmatic source has been surely fixed. Its activity was manifested $\sim 2.0 \mathrm{Ga}$, most of the mantle (juvenile) magmas crystallized without contamination with crustal material.

\section{Acknowledgement}

We thank Vinod Singh for his help with preparing this publication. This study has been carried out following the plans of the scientific research of the Geological Institute of RAS (project № 0135-2016-0009). The analytical data were obtained using instrumentation funded by DEST Systemic Infrastructure Grants, ARC LIEF, NCRIS/Au Scope, industry partners and Macquarie University, and ARC FT110100-685 grant support (Belousova EA.). This is contribution 1105 from the ARC Centre of Excellence for Core to Crust Fluid Systems (http://www.ccfs.mq.edu.au) and 1211 in the GEMOC Key Centre. Handling of geochemical data, analysis processing, the regional geological materials gathering, publication preparation were executed with partial support of the Ministry of Science and Education of RF (project 14.Z 50.31.0017), RSF (grant 14-27-00058) and RFBR (grants 16-05-00259 and16-05-00519).

\section{References}

1. Gorozhanina EN, Gorozhanin VM, Kuznetsov NB, Romanyuk TV (2014) Features of the composition and structure of the terrigenous deposits of Ordovician in the sections of the southeast of the Russian platform and the Southern Urals. Geological digest, Arizona, USA, pp. 97-115.

2. Puchkov VN (2010) Geology of the urals and cis-urals. Design Polygraph Service, Russia, p. 280.

3. Ryazantsev AV, Belova AA, Razumovsky AA, Kuznetsov NB (2012) Geodynamic formation settings of Ordovician and Devonian complexes in ophiolitic sections of the Southern Urals and Mugoszhary. Geo-tectonics 46(2): 142-169.

4. Ryazantsev AV, Dubinina SV, Kuznetsov NB, Belova AA (2008) Ordovician lithotectonic complexes in allochthons of the Southern Urals. Geotectonics 42(5): 368-395.

5. Panteleyev AS, Kozlov NF (1997) Geological structure and oil and gas content of the Orenburg region. Orenburg, Russia, p. 272.

6. Romanyuk TV, Kuznetsov NB, Maslov AV, Belousova EA, Krupenin MT, et al. (2014) Geochemical and Lu/Hf Isotopic (LA_ICP_MS) signature of detrital zircons from sandstones of the basal levels of the riphean stratotype. Doklady Earth Sciences 459(1): 1356-1360.

7. Galimov AG, Makarova SP (1998) Composition and structure of the preRiphean basement of the southeastern part of the Volga-Urals anteclise. In: Panteleev AS, Kozlov NFO (Eds.), Geology and development of oil and gas fields in the Orenburg region, Russia, pp. 31-37.

8. Volozh Yu A, Parasyna VS, Nauchniy M (2013) Orenburg tectonic node: Geological structure and petroleum potential. Mir publishers, Moscow, Russia, p. 264.
9. Politykina MA, Tyurin AM, Bagmanova SV (2001) Ordovician deposits of the Sol-Iletsky arch and adjacent areas. Forecast of oil and gas potential of the basement of young and ancient platforms. Kazan University, Moscow, Russia, pp. 318-321.

10. Gorozhanina EN, Chibrikova EV, Olli VA (2012) Lithology and conditions for the accumulation of Ordovician deposits of the southeast of the Russian platform, priority and innovation directions of lithological studies. IGG UrB RAS, Ekaterinburg, Russia, pp. 33-35.

11. Griffin WL, Belousova EA, Shee SR, Pearson NJ, Oreilly SY (2004) Archean crustal evolution in the northern yilgarn craton: U-Pb and Hfisotope evidence from detrital zircons. Precambrian Research 131(3-4): 231-282.

12. Griffin WL, Belousova EA, Walters SG, Oreilly SY (2006) Archean and Proterozoic crustal evolution in the Eastern succession of the Mt Isa district, Australia: U-Pb and Hf-isotope studies of detrital zircons. Australian Journal of Earth Sciences 53: 125-149.

13. Veevers JJ, Saeed A, Belousova EA, Griffin WL (2005) U-Pb ages and source composition by Hf-isotope and trace-element analysis of detrital zircons in Permian sandstone and modern sand from southwestern Australia and a review of the paleo-geographical and denudational history of the Yilgarn Craton. Earth Science Reviews 68(3-4): 245-279.

14. Belousova EA, Griffin WL, Reilly SY (2006) Zircon crystal morphology, trace element signatures and $\mathrm{Hf}$ isotope composition as a tool for petrogenetic modeling: Examples from eastern Australian granitoids. Journal of Petrology 47(2): 329-353.

15. Belousova EA, Walters S, Griffin WL, Reilly SY, Fisher NI (2002) Igneous zircon: trace element compositions as indicators of source rock type. Contributions to Mineralogy and Petrology 143(5): 602-622.

16. Romanyuk TV, Kuznetsov NB, Belousova EA, Gorozhanin VM, Gorozhanina EN (2018) Paleotectonic and paleo-geographic conditions for the accumulation of the Lower Riphean Ai Formation in the Bashkir Uplift (Southern Urals): The Terrane Chrone ${ }^{\circledR}$ detritalzircon study. Geodynamics \& Tectonophysics 9(1): 1-37.

17. Griffin WL, Pearson NJ, Belousova EA, Jackson SE, Reilly SY, et al. (2000) The Hf isotope composition of cratonic mantle: LAM_MC_ICPMS analysis of zircon megacrysts in kimberlites. Geochimica et Cosmochimica Acta 64(1): 133-147.

18. Jackson SE, Pearson NJ, Griffin WL, Belousova EA (2004) The application of laser ablation-inductively coupled plasma-mass spectrometry to in situ U-Pb zircon geochronology. Chemical Geology 211(1-2): 47-69.

19. Ludwig KR (2001) Berkeley Geochronology Center. Special Publication A, Berkeley, California, 1: 56.

20. Vermeesch P (2012) On the visualisation of detrital age distributions. Chemical Geology 312-313: 190-194.

21. Hoskin PO, Ireland TR (2000) Rare earth element chemistry of zircon and its use as aprovenance indicator. Geology 28(7): 627-630.

22. Belousova EA, Gonzalez JM, Graham JI, Griffin WL, Reilly SY, et al. (2015) The enigma of crustal zircons in upper-mantle rocks: Clues from the Tumut ophiolite, southeast Australia. Geology 43(2): 119-122.

23. Grimes CB, John BE, Kelemen PB, Mazdab FK, Wooden JL, et al. (2007) Trace element chemistry of zircons from oceanic crust: A method for distinguishing detrital zircon provenance. Geology 35: 643-646.

24. Grimes CB, Wooden JL, Cheadle MJ, John BE (2015) "Fingerprinting" tectono-magmatic provenance using trace elements in igneous zircon. Contributions to Mineralogy and Petrology 170: 46.

25. Kaczmarek MA, Müntener O, Rubatto D (2008) Trace element chemistry and $\mathrm{U}-\mathrm{Pb}$ dating of zircons from oceanic gabbros and their relationship with whole rock composition (Lanzo, Italian Alps). Contributions to Mineralogy and Petrology 155(3): 295-312. 
26. Kirkland CL, Smithies RH, Taylor RJM, Evans N, McDonald B (2015) Zircon Th/U ratios in magmatic environs. Lithos 212-215: 397-414.

27. Hoskin PO, Schaltegger U (2003) The composition of zircon and igneous and metamorphic petrogenesis. Reviews in Mineralogy and Geochemistry 53(1): 27-62.

28. Teipel U, Eichhorn R, Loth G, Rohrmuller J, Holl R, et al. (2004) U-Pb SHRIMP and Nd isotopic data from the western Bohemian Massif (Bayerischer Wald, Germany): Implications for Upper Vendian and Lower Ordovician magmatism. International Journal of Earth Sciences 93(5): 782-801.

29. Heaman LM, Bowins R, Crocket J (1990) The chemical composition of igneous zircon suites: implications for geochemical tracer studies. Geochimica et Cosmochimica Acta 54(6): 1597-1607.

30. Linnemann U, Ouzegane K, Drareni A, Hofmann M, Becker S, et al. (2011) Sands of West Gondwana: An archive of secular magmatism and plate interactions a case study from the Cambro-Ordovician section of the Tassili Ouan Ahaggar (Algerian Sahara) using U-Pb-LA-ICP-MS detrital zircon ages. Lithos 123(1-4): 188-203.

31. Wanless VD, Perfit MR, Ridley WI, Wallace PJ, Grimes CB, et al. (2011) Volatile abundances and oxygen isotopes in basaltic to dacitic lavas on mid-ocean ridges: the role of assimilation at spreading centers. Chemical Geology 287(1-2): 54-65.

32. Rubatto D, Hermann J (2007) Experimental zircon/melt and zircon/ garnet trace element partitioning and implication for the geochronology of crustal rocks. Chemical Geology 241(1-2): 38-61.

33. Yuan HL, Gao S, Dai MN, Zong CL, Gunther D, et al. (2008) Simultaneous determinations of $\mathrm{U}-\mathrm{Pb}$ age, $\mathrm{Hf}$ isotopes and trace element compositions of zircon by excimer laser-ablation quadrupole and multiple-collector ICP-MS. Chemical Geology 247(1-2): 100-118.

34. Scherer E, Münker C, Mezger K (2001) Calibration of the Lu-Hf clock Science 293(5): 683-687.

35. Bouvier A, Vervoort JD, Patchett PJ (2008) The Lu-Hf and Sm-Nd isotopic composition of CHUR: constraints from unequilibrated chondrites and implications for the bulk composition of terrestrial planets. Earth and Planetary Science Letters 273(1-2): 48-57.

36. Belousova EA, Kostitsyn YA, Griffin WL, Begg GC, Oreilly SY, et al. (2010) The growth of the continental crust: Constraints from zircon Hf-isotope data. Lithos 119: 457-466.

37. Liu J, Liu F, Ding Z, Yang H, Liu C, et al. (2013) U-Pb dating and Hf isotope study of detrital zircons from the Zhifu Group, Jiaobei Terrane, North China Craton: Provenance and implications for Precambrian crustal growth and recycling. Precambrian Research 235: 230-250.

38. Corfu F, Hanchar JM, Hoskin PWO, Kinny P (2003) Atlas of Zircon Textures. Reviews in Mineralogy and Geochemistry 53(1): 469-500.

39. Yang Z, Woolley AR (2006) Carbonatites in China: A review. Journal of Asian Earth Sciences 27(5): 559-575.

40. Kuznetsov NB, Gorozhanin VM, Belousova EA, Degtyarev KE, Gorozhanina EN, et al. (2017) The first results of U/P b dating of detrital zircons from Ordovician terrigenous sequences of Sol-Iletsk arch of the East-European Platform. Doklady Earth Sciences 473(2): 381-385.

41. Glorie S, Zhimulev FI, Buslov MM, Andersen T, Plavsa D, et al. (2015) Formation of the Kokchetau subduction-collision zone (northern Kazakhstan): Insights from zircon. Gondwana Research 27: 424-438.

42. Kuznetsov NB, Maslov AV, Belousova EA, Romanyuk TV, Krupenin MT, et al. (2013) The First U-Pb (LA-ICP-MS) Isotope Data of Detrital Zircons from the Basal Levels of the Riphean Stratotype. Doklady Earth Sciences 451(1): 724-728.

43. Tevelev AV, Kosheleva IA, Khotylev AO, Moseichuk VM, Petrov VI
(2015) New data on the isotopic ages of the Taratash and Alexandrovka metamorphic complexes. Moscow University Geological Bulletin 70(1): 24-70.

44. Ronkin Yu L, Gerdes A, Nesbit R (2015) Zircon of the granites rapakivi and associating rocks of the Southern Urals: REE and Lu-Hf isotopic constraints. Proceedings of Institute of Geology and Geochemistry 162: 222-228.

45. Terentiev RA, Savko KA, Santosh M (2016) Paleoproterozoic crustal evolution in the East Sarmatian Orogen: petrology, geochemistry, Sr-Nd isotopes and zircon $\mathrm{U}-\mathrm{Pb}$ geochronology of andesites from the Voronezh Massif, Western Russia. Lithos 246-247: 61-80.

46. Savko KA, Samsonov AV, Larionov AN, Larionova Yu O, Bazikov NS (2014) Paleo-proterozoic A and S-granites in the eastern Voronezh crystalline massif: geochronology, petrogenesis, and tectonic setting of origin. Petrology 22(3): 205-233.

47. Wu F, Yang Y, Li Q, Mitchell RH, Dawson JB, et al. (2011) In situ determination of $\mathrm{U}-\mathrm{Pb}$ ages and $\mathrm{Sr}-\mathrm{Nd}-\mathrm{Hf}$ isotopic constraints on the petrogenesis of the Phalaborwa carbonatite Complex, South Africa. Lithos 127(1-2): 309-322.

48. Tichomirowa M, Whitehouse MJ, Gerdes A, Götze J, Schulz B, et al. (2013) Different zircon recrystallization types in carbonatites caused by magma mixing: Evidence from U-Pb dating, trace element and isotope composition ( $\mathrm{Hf}$ and $\mathrm{O}$ ) of zircons from two Precambrian carbonatites from Fennoscandia. Chemical Geology 353: 173-198.

49. Rukhlov AS, Bell K, Amelin Y (2015) Carbonatites, isotopes and evolution of the subcontinental mantle: An overview. Symposium on critical and strategic materials. British Columbia Geological Survey Paper 3: 39-64.

50. Rubin JN, Henry CD, Price JG (1993) The mobility of zirconium and other "immobile" elements during hydrothermal alteration. Chemical Geology 110(1-3): 29-47.

51. Zhao G, Li S, Sun M, Wilde SA (2011) Assembly, accretion, and break-up of the Palaeo-Mesoproterozoic Columbia supercontinent: Record in the North China Craton revisited. International Geology Review 53(11-12): 1331-1356.

52. Bibikova EV, Kirnozova TI, Fugzan MM, Bogdanova SV, Postnikov AV, et al. (2009) Sarmatia-Volgo-Uralia junction zone: isotopic-geochronologic characteristic of supracrustal rocks and granitoids. Stratigraphy and Geological Correlation 17: 561.

53. Bogdanova SV, Bingen B, Gorbatschev R, Kheraskova TN, Kozlov VI, et al. (2008) The east European craton (Baltica) before and during the assembly of Rodinia. Precambrian Research 160(1-2): 23-45.

54. Sharkov EV (2010) Middle-proterozoic anorthosite-rapakivi granite complexes: An example of within-plate magmatism in abnormally thick crust: Evidence from the east European craton. Precambrian Research 183(4): 689-700.

55. Shumlyanskyy L, Nosova A, Billstrom K, Soderlund U, Andreasson PG, et al. (2016) The U-Pb zircon and baddeleyite ages of the Neoproterozoic Volyn Large Igneous Province: Implication for the age of the magmatism and the nature of a crustal contaminant. Geologiska Foreningen 138(1): $1-14$.

56. Kuznetsov NB, Belousova EA, Alekseev AS, Romanyuk TV (2014a) New data on detrital zircons from the sandstones of Lower Cambrian Brusov Formation (White-Sea region, East-European craton): unraveling the timing of the onset of the Arctida-Baltica collision. International Geology Review 56(16): 1945-1963.

57. Kuznetsov NB, Belousova EA, Romanyuk TV, Degtyarev KE, Maslov AV et al. (2017a) The first results of $\mathrm{U} / \mathrm{Pb}$ dating detrital zircons from sandstones of Zigalga Formation (Middle Riphean, the South Urals. Doklady Earth Sciences 475(2): 862-866. 
58. Romanyuk TV, Maslov AV, Kuznetsov NB, Belousova EA, Ronkin Yu L, et al. (2013) The first results of U/Pb LA-ICP-MS Dating of detrital zircons from Uppermost Neoproterozoic sandstones Bashkir anticlinorium (Southern Urals). Doklady Earth Sciences 452(2): 997-1000.

59. Kuznetsov NB, Meert JG, Romanyuk TV (2014) Ages of the detrital Zircons (U/Pb, La-ICP-MS) from Latest Neoproterozoic-Middle Cambrian(?) Asha Group and Early Devonian Takaty Formation, the South-Western Urals: a Testing of an Australia-Baltica Connection within the Rodinia. Precambrian Research 244: 288-305.

60. Kuznetsov NB, Romanyuk TV, Shatsillo AV, Orlov S Yu, Golovanova I, et al. (2012) The first results of the bulk U/Pb-dating of detrital zircons (LAICP-MS) from Asha Formation, the Southern Urals - the stratigraphic, paleogeographic and paleo-tectonic aspects. Doklady Earth Sciences 447(1): 1240-1246.

61. Kuznetsov NB, Belousova EA, Degtyarev KE, Pyzhova ES, Maslov AV, et al. (2016) The First results of the U/Pb Dating of detrital Zircons from the
Later Ordovician sandstones of the Bashkir Uplifts (the Southern Urals). Doklady Earth Sciences 467(2): 325-330.

62. Degtyarev K, Yakubchuk A, Tretyakov A, Kotov A, Kovach V (2017) Precambrian geology of the Kazakh uplands and Tien Shan: An Overview. Gondwana Research 47: 44-75.

63. Kovach V, Kotov A, Tolmacheva E, Degtyarev K, Tretyakov A, et al. (2017) Sources and provenance of the Neoproterozoic placer deposits of the Northern Kazakhstan: Implication for continental growth of the western central Asian orogenic belt. Gondwana Research 47: 28-43.

64. Degtyarev KE, Shatagin KN, Tretyakov AA (2016) Sources of Paleozoic granitic rocks and isotopic heterogeneity of the continental crust of the Aktau-Dzhungar microcontinent, Central Kazakhstan. Doklady Earth Sciences 470(2): 1010-1013.
Creative Commons Attribution 4.0 International License

For possible submissions Click Here
Submit Article

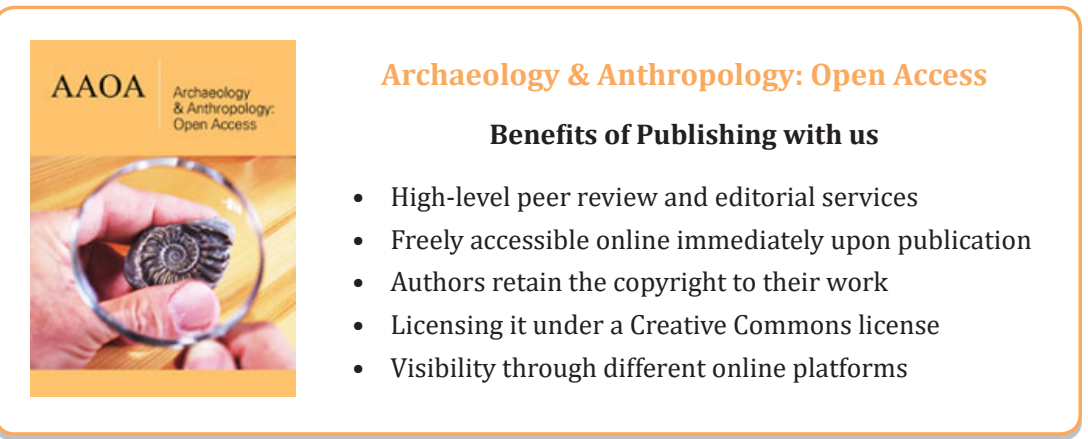

